\title{
THE LEGAL PROBLEMS OF EDUCATIONAL TELEVISION
}

The value of educational television has increased with the rapid development of the medium. ${ }^{1}$ Reaching large audiences and inducing in them a high degree of concentration, telecasts represent an effective source of both in-school and adult education. Fully utilized, educational television can improve inschool instruction and relieve teacher shortages by allowing superior instructors intimate contact with large audiences in separate classrooms. ${ }^{2}$ Adult education can be served through the offering of university courses in the home, ${ }^{3}$ and society generally through the broadcast of nonacademic programs of a higher educational and cultural content than the typical commercial television show. Currently, thirty educational television stations in twentyone states and one territory, with a potential audience of fifty million, are supplying these types of programming. In addition, a more restricted type

1. Information on the organization, financing and broadcasting practices of educational television stations was obtained through questionnaires sent to every station (twenty-eight) operating in September of 1957 (hereinafter cited as QuestronNarres). Replies were received from twenty-four. The editors of the Yale Law Journal acknowledge with gratitude the co-operation of these stations in making available this information.

For general surveys of the growth and usefulness of educational television, see JoINT Council on Enucational Television, Four Years of Progress in Educational Teievision (1956) ; ETV : 5 Years and $\$ 60$ Million Later, Broadcasting-Telecasting, Nov. 11, 1957, pp. 94-103; The Reporter, May 30, 1957, pp. 9-20.

2. See Bakal, The Schools of Tomorrow, Saturday Review of Literature, Aug. 24, 1957, p. 9; The most extensive experiment in the use of in-school television is in Hagerstown, Maryland, where, by September 1958, present instruction through a closed-circuit system will extend to forty-eight schools with 18,000 pupils. Testimony of Ralph Steetle, Executive Director, Joint Council on Educational Television, Hearings Before the Federal Communications Commission in the .lfatter of Allocation of Frequencies in the Bands .Aboz' S90 M/cgacycles, No. 11866 (1957). The most extensive plan currently under consideration is a closed-circuit network embracing 309 colleges and universities in sixteen southern states and televising fifty courses each semester. On the assumption that students will receive one third of their course time on television, instructional costs have been estimated at $\$ 2.80$ per student per semester hour as compared with $\$ 12-18$ per student per semester hour under the present system. Testimony of Robert $C$. Anderson, Director, Southern Regional Education Board, Hearings, supra.

3. Viewers who wish to receive degree credit for these courses register at the university concerned and take a final examination. For a discussion of the current adult instruction program of New York City universities, see N.Y. Times, Feb. 6, 1958, p. 55, col. 2. See also Broadcasting-Telecasting, Sept. 23, 1957, p. 102.

The educational station in Memphis has used television to teach 1,000 illiterates how to read and write. Broadcasting-Telecasting, Nov. 11, 1957, p. 95.

4. As of February 1, 1958, educational television stations were operating in the following localities: Andalusia, Birmingham and Mumford, Ala.; San Francisco, Cal.; Denver, Colo.; Miami, Fla.; Champaign-Urbana and Chicago, Mll.; Monroe and New Orleans, La.; Rioston, Mass.; Detroit and East Lansing, Mich.; Minneapolis-Saint Paul, Minn.; St. Louis, Mo.; Lincoln, Neb.; Chapel Hill, N.C.; Cincinnati and Columbus, Ohio; Oklahoma City, Okla.; Corvallis, Ore.; Philadelphia and Pittsburgh, Pa.; San Juan, P.R.; Memphis, Tenn.; Houston, Tex.; Salt Lake City, Utah; Seattle, Wash.; Milwaukee and Madison, 
of telecasting-closed-circuit television-has been installed in 103 educational institutions throughout the country. ${ }^{5}$

Because their programming objectives are more specialized, educational television stations differ from their commercial counterparts. Ownership is limited to organizations formed for educational purposes, to insure that the aims of such institutions will shape programming. ${ }^{b}$ Similarly, the pressure of sponsor demands for noneducational, mass-appeal programs is countered: educational stations must be operated by nonprofit organizations and may not raise funds by selling time. ${ }^{7}$ These requirements in turn have affected channel allocation policies. Since organizational and financial restrictions may seriously impair their ability to compete for broadcasting channels, educational television stations operate on special facilities reserved by the Federal Communications Commission. ${ }^{8}$

Often, however, the programming of commercial and noncommercial stations is similar. Commercial stations are encouraged to broadcast both inschool and adult education programs. ${ }^{9}$ Conversely, educational stations tailor their telecasts to achieve a maximum popular appeal consistent with the nature

Wis. Five stations were scheduled to start broadcasting in 1958, in Jacksonville, Fla.; Athens and Atlanta, Ga.; Albuquerque, N.M.; and Oxford, Ohio. Joint Council oN Educational Television, Fact Sheet \& Box Score (Feb. 1958).

5. Testimony of Ralph Steetle, Hearings, supra note 2, at 6 . In open-circuit broadcasting, transmission to the viewer takes place through the atmosphere. All sets within the range of the signal are able to receive it. In closed-circuit broadcasting, the signal travels exclusively by wire or cable, and only connected television sets are able to receive it.

6. 47 C.F.R. § 3.621 (a) (Supp. 1957); see notes 63-67 infra and accompanying text.

7. 47 C.F.R. § 3.621 (d) (Supp. 1957); see notes 86-88 infra and accompanying text.

8. See notes 26-36 infra and accompanying text.

9. The FCC grants licenses partly on the basis of the proposed programming of the applicant. Stations proposing superior educational programming have sometimes been accorded a preference over competing applicants. See Television City, Inc., 14 PIKE \& Fischer Radio REg. 333, 462b (1956) (hereinafter cited as Radio REg.); Traveller's Broadcasting Serv., 12 Radro REg. 689, 747-49, 806 (1956) ; Columbia Amusement Co., 12 RAdio REg. 509, 534-35, 560 (1956). The FCC has specifically stated that the special provisions made for noncommercial educational stations do not relieve commercial licensees from their duty to carry educational programs, even if an educational station is operating in the same community. Sixth Report and Order, 1 Radio REg. 91:601, 616 (1952). The carrying of educational programs is part of a commercial licensee's public-service responsibility, the fulfillment of which the FCC will take into account when considering requests for license renewals every three years. See FCC, Public Service Responsibility of BROADCAST LiCENSEES 15-16 (1946).

It is sometimes difficult to distinguish "educational" from entertainment programs. Most entertainment programs impart some educational information, even if it be only an insight into the way of life of the Wild West. And educational programs must present their material in an entertaining fashion to achieve maximum effectiveness. The FCC defines "educational" narrowly as including only programs prepared by or in behalf of educational organizations. Application for Authority to Construct a New Broadcast Station or Make Changes in Existing Broadcast Station, 1 Radio REG. 98:101 (1954). This definition excludes commercial childrens' programs, like "Ding Dong School," or student-participation programs, like "Youth Wants to Know" or "Campus Press Conference." For illustrations of commercial station broadcasts which qualify as "educational" under the 
of the subject matter. Where this dual programming is directed to a single market, competition for audience -replaces the forbidden competition for sponsors. And since attraction and maintenance of an audience is the significant commodity a commercial station offers sponsors, audience competition materially affects commercial revenues.

A noncommercial institution thus functioning in a traditionally commercial area, educational television presents unique legal problems. Specifically, in the area of station licensing, the scarcity of available channels for commercial broadcasting necessitates a determination of the extent to which unused facilities should continue to be reserved for educational stations. In the field of station finance, where educational stations are necessarily dependent upon public and private contributions, those relationships with commercial organizations which constitute allowable benefactions must be satisfactorily distinguished from those which are illegal sales of time. Finally, the liability of educational stations for invasion of privacy and copyright infringement should be determined. Developed in response to commercial operations, both doctrines need be adapted to the peculiar noncommercial and public-service nature of educational broadcasters.

\section{LICENSING}

From the first use of radio to the more recent development of television, two conflicting theories have prevailed on the optimum utilization of broadcasting for the furtherance of education. The commercial broadcasting industry, interested in maximum self-development through monopolization of available facilities, has maintained that special educational programs carried by commercial stations would most effectively advance scholastic goals. ${ }^{10}$ On this view, educators could reach a maximum audience without entering unfamiliar fields of station engineering, management and finance. Implicit in the suggestion is, of course, the fear of low-cost competition from programs disseminated by nonprofit, tax-free institutions. ${ }^{11}$ Educational interests, in contrast, regard the time available on commercial stations as inadequate and believe that educational needs can be filled only by separate educational outlets. ${ }^{12}$

FCC definition, see N.Y. Times, Sept. 26, 1957, p. 51, col. 1 ; ETV: 5 Years and $\$ 60$ Million Later, Broadcasting-Telecasting, Nov. 11, 1957, pp. 99-100.

Programs currently televised by commercial stations offer instruction in Russian language (Schenectady, N.Y.), engineering (New York City), music appreciation (Norfolk, Va.), and literature (New York City), and lectures on earth satellites and lunar flight (Los Angeles, Cal.). N.Y. Times, Feb. 2, 1958, § 2, p. 15, cols. 4-7.

10. FCC, Report Pursuant to $\$ 307$ (c) of the Comminications Act 2-4 (1935) (hereinafter cited as FCC REPORT); Broadcasting-Telecasting, Nov. 11, 1957, p. 120. When the Communications Act was before Congress, owners of large commercial stations expressed their willingness to allot, as a condition of their license, a given percentage of their time for use by nonprofit organizations. 78 CoNG. REC. 8843 (1934).

11. Broadcasting-Telecasting, Nov. 11, 1957, p. 122. For a discussion of the possible effects of competition for sponsors, see notes 97-100 infra and accompanying text.

12. The basis of the argument is that commercial stations which do allocate time to educators do so irregularly and only during hours (early in the morning or late at night, 
Congress considered these conflicting arguments when writing the Communications Act of 1934 , the basic statute regulating broadcasting. ${ }^{13}$ Most noncommercial educational stations previously licensed had encountered insuperable financial difficulties and discontinued operation. ${ }^{14}$ To revive educational broadcasting, a plan to reserve twenty-five per cent of broadcasting facilities for stations operated by nonprofit organizations was proposed in Congress. ${ }^{15}$ The financial limitations inherent in noncommercial broadcasting were to be remedied by permitting sale of sufficient time to advertisers to defray the cost of station operations. ${ }^{16}$ Prompted by the fear that the sale of time would dilute the desired nature of the stations' programming, Congress rejected this aspect of the proposal. ${ }^{17}$ And rather than taking direct action itself, it submitted the reservations plan to the Federal Communications Commission for study. ${ }^{18}$ This action was consistent with congressional desire, obvious throughout the act, to make use of the Commission's administrative expertise and achieve a flexible allocations pattern. ${ }^{19}$

for example) when potential audiences are small. Educators fear they would also have to exclude from their programming subjects that would be controversial or might alienate the commercial stations' advertisers. All these factors, the argument runs, prevent significant use of commercial facilities. Hearings Before the Federal Communications Commission in the Matter of Allocations of Frequencies From Ten to Thirty Million Kilocycles 1611 (1944). See also 78 Cong. Rec. 8844 (1934).

13. 48 Stat. 1082 (1934), as amended, 47 U.S.C. § 303 (1952).

14. In the first four years of AM broadcasting (1921-25), 171 licenses were granted to educational institutions. Hearings, supra note 12, at 15975. From 1927 to 1934, the Federal Radio Commission issued over 100 other licenses to educational institutions. However, most of these stations had, by 1934, assigned their franchises to commercial stations. Id. at 1416 . As a result, by 1934 , noncommercial stations comprised only $2 \%$ of the total number of stations on the air. 78 CoNG. REC. 8829 (1934).

15. The facilities would have been available to "educational, religious, agricultural, labor, cooperative, and similar non-profit-making associations." Id. at 8828-29.

16. " $(\mathrm{g})$.... In the distribution of radio facilities to the associations referred to in this section, the Commission shall reserve for and allocate to such associations such radio broadcasting facilities as will reasonably make possible the operation of such stations on a self-sustaining basis, and to that end the licensee may sell such part of the alloted time as will make the station self-supporting." Id. at 8829 .

17. The following exchange took place in the debate between Senator Dill, Chairman of the Senate Committee on Interstate and Foreign Commerce and Floor Manager for the Communications Act, and Senator Fess, a supporter of the amendment:

"Senator Dill : ... [I]t is proposed ... to grant 25 per cent of the radio facilities to those who call themselves educational, religious, nonprofit stations, but who in reality are planning to ... sell a tremendous amount of their time for commercial purposes. That is not what the people of this country are asking for.

"Senator Fess: That is not quite what I had in mind.

"Senator Dill: ... [A]nd if time is sold to a commercial purchaser, he is going to advertise. $\mathrm{He}$ is not going to pay for time unless he does advertise.

"In my judgement, therefore, this amendment falls of its own weight." Id. at $8 \& 30$. Senator Dill estimated that stations would have to sell between sixty and seventy-five per cent of their time to finance operations. Id. at 8843 .

18. 48 STAT. 1084 (1934), as amended, 47 U.S.C. $\$ 307$ (c) (1952).

19. "[I]n writing the radio law ... we avoided directing the Commission to assign particular radio facilities or any particular percentage of facilities to any particular 
After hearings, the FCC found that maximum educational value and minimum disruption of allocations flexibility would result if no special reservations were made. ${ }^{20}$ The Commission sought to advance these objectives by making educational programming a public-service responsibility of commercial licensees. ${ }^{21}$ This arrangement, however, produced inadequate educational broadcasting. ${ }^{22}$ Accordingly, ten years after its initial consideration of the problem, when the development of frequency modulation-FM-had expanded broadcasting facilities, the FCC reversed this policy and set aside channels exclusively for educational use. ${ }^{23}$ Since the reservations scheme met with some success, ${ }^{24}$ and since television was potentially a far more promising educational instrument than radio, a similar policy was continued in the 1952 allocations of television facilities. ${ }^{25}$

Both educational and commercial television licenses are granted on the basis of a nationwide schedule which allocates channels to communities, roughly in proportion to the population included within the range of a prospective station's signal. ${ }^{26}$ These channels comprise the very-high-frequency bandchannels two through thirteen-and the ultra-high-frequency band-channels

service, believing that that was a matter that the Commission should determine on the basis of public interest." Statement of Senator Dill, Chairman of the Senate Committee on Interstate and Foreign Commerce, Senate Hearings on S. 2910, 73d Cong., 2d Sess. 190-91 (1934), quoted in 7 RAdro REg. 380 (1951).

"If we begin to take away from the . . Conmission its authority to allocate, . . we would probably get in a lot of trouble." Representative Rayburn, Chairman of the House Interstate and Foreign Commerce Committee, arguing against the amendment allocating facilities to nonprofit associations, 7S CoNG. REC. 10315-16 (1934).

20. FCC REPORT 5. This conclusion was based on the finding that commercial stations were willing to carry programs of noncommercial organizations and that this procedure would adequately serve the desired purpose. Id. at 9-10. By the time of the television allocations, however, the FCC had come around, on the basis of experience, to the opposite conclusion: "[T]his sort of voluntary cooperation cannot be expected to accomplish all the important objectives of educational television." Sixth Report and Order, 1 RAdio REG. 91 :601, 615 (1952).

21. FCC REPORT 10.

22. Hearings, supra note 12 , at 1611 . In addition, little progress had been made in the establishment of separate noncommercial educational stations. As of 1945, only five such stations were on the air, four more were under construction and applications were pending for eight others. Id. at 1418 .

23. FCC, Report of Proposed Allocations From 25,000 Kilocycles to $30,000,000$ KroCYCTES 77 (1945). The FCC allocated twenty channels in the FM band exclusively for educational use. 47 C.F.R. $\$ 3.501$ (Supp. 1957). For the regulations governing noncommercial educational FM stations, see $i d$. $\S \S 3.501-.591$. The regulations governing ownership and financing are similar to educational television regulations. Compare id. $\$ 3.503$, with id. \& 3.621 .

24. See Sixth Report and Order, 1 RADro REG. 91 :601, 613 (1952).

25. Id. at 611 .

26. For the allocations table, listing channel assignments to each community, see 47 C.F.R. $\$ 3.606$ (b) (Supp. 1957). For the FCC's detailed discussion of each allocation, see 1 RADIo REG. 91:601, 691-1002a (1952). The F.CC's power to formulate a nationwide allocations scheme was upheld in Logansport Broadcasting Corp. v. United States, 210 F.2d 24 (D.C. Cir. 1954). 
fourteen through eighty-three. ${ }^{27}$ Since station assignments on any one channel are geographically spaced to avoid electrical interference, applicants may seek only those channels already allocated to the community. ${ }^{28}$ Concluding that educational institutions would require more time than commercial interests to prepare for television broadcasting, the FCC reserved eighty-six VHF station assignments for noncommercial educational use to insure that available facilities in important areas would not be appropriated before educators could complete their preparations. ${ }^{29}$ Because VHF channels were considered technically superior to $\mathrm{UHF},{ }^{30}$ a VHF channel was reserved in every locality which received three or more VHF allocations, except those in which all VHF channels had previously been assigned. ${ }^{31} \mathrm{~A}$ VHF station was also reserved

27. "Each television station operates on a 6-megacycle channel or wave length assigned to it by the Federal Communications Commission. There are 82 such channels, 12 of them ... in the very-high-frequency (VHF) portion of the radio spectrum and 70 of them ... in the ultra-high-frequency (UHF) band. Each band was assigned to television at a different stage of television's development and each has different technical qualities." Plotkin, Memorandum Prepared for the Senate Committee on Interstate and Forcign Commerce, 84th Cong., 1st Sess. 8-10 (1955).

28. See Logansport Broadcasting Corp. v. United States, 210 F.2d 24, 26 (D.C. Cir. 1954). If only one application is made for a channel, the FCC grants a license if it finds the applicant legally, financially and technically qualified and concludes that the public interest will be served by the grant. 48 STAT. 1085 (1934), as amended, 47 U.S.C. § 309 (a) (1952). A grant to a sole applicant may be protested within thirty days. For the procedure on protest, see Note, 67 YALE L.J. 135 n.3 (1957).

If more than one application for a channel is made, the FCC holds a comparative hearing on the applicants' merits. For the procedure in comparative hearing cases, see 47 C.F.R. $\$ 1.802-96$ (Supp. 1957). For discussion, see Schilz, New Techniques for Expediting Hearings in FCC Proceedings, 55 Colum. L. Rev. 830 (1955).

29. Sixth Report and Order, 1 Radio REG. $91: 601,612$ (1952). For discussion of each reservation, see $i d$. at $691-1002 \mathrm{a}$.

30. Id. at 607 . UHF signals do not travel as far as VHF signals because they are more sensitive to rough terrain and bend less easily with the curvature of the earth. Note, 67 Y ALE L.J. 135, 144 n.36 (1957).

31. Between 1948 and 1952, while the FCC worked out its nationwide allocations plan, no new television applications were accepted. However, $108 \mathrm{VHF}$ stations had already been licensed before this "freeze." In some of the largest cities, including New York, Los Angeles, Detroit, Buffalo, Cincinnati, Cleveland, Philadelphia, Baltimore and Washington, all VHF channels had already been granted. This forced educational television onto UHF channels. See Sixth Report and Order, 1 Rapio Reg. 91 :601, 1035-37 (1952) (separate views of Comm'r Hennock). The failure of the UHF band, see note 37 infra, has resulted in no educational television in most of these cities, a serious impediment to progress since they offer both a large percentage of the nation's population and important sources of educational programming. Short of appropriation of channels from operating commercial licensees, the only way educators can obtain a VHF channel in these cities is through purchase. The current price of a VHF channel in a large city is far beyond the current outlays for single-city educational television. See, e.g., Broadcasting-Telecasting, Jan. 6, 1956, p. 56 (Philadelphia channel sold for $\$ 12,600,000$ ).

In December 1957, the New York State Board of Regents petitioned the FCC to reassign for educational use one of the seven commercial VHF channels in the New York City metropolitan area. The station was for sale, at a reported price of over $\$ 4,000,000$. The Regents' petition said: "An opportunity is now presented, perhaps the only oppor- 
in twenty-six small communities designated "educational centers," in order to foster education in areas of sparse population which contained the resources of a university. ${ }^{32}$ Since an educational institution is not barred from applying for an unreserved channel, the significance of the reservations scheme to the encouragement of educational television is apparent. ${ }^{33}$

The effect of the Commission's reservations policy is to prefer the advancement of educational television to important commercial goals. To allocate available facilities in the fullest and most equitable manner, the FCC had given first allocation priority to supplying every area of the nation with service from at least one television station. Second priority was accorded to the establishment of a local station in every community. Once these essentials were satisfied, the FCC gave next priorities to a second area service, then to a second local station and ultimately to the promotion of competition between networks and stations in order to maximize the viewer's possible choice of programs. ${ }^{34}$ The plan for educational allocations was superimposed upon these priorities. Thus, when an educational reservation deprived a second, third or fourth network of an outlet, encouragement of competition between networks was subordinated to the needs of educational television. ${ }^{35}$ Even the drive for earliest possible estab-

tunity that will ever be presented, for converting a [VHF] channel in the New York City area to educational use without injury, financially or otherwise, to an existing licensee or operator." After reassignment, the Regents said it would then negotiate purchase at "a fair price." Commercial interests were offering a reported $\$ 4,000,000$ for the station. N.Y. Times, Dec. 6,1957 , p. 1, col. 5 . The Regents subsequently withdrew its petition. N.Y. Times, March 6,1955 , p. 55 , col. 4 . Instead, the Regents has tentatively arranged to lease substantial broadcast time (nine hours a day, three hours Saturday) from the licensee of another New York City channel. N.Y. Times, March 11, 1957, p. 1, cols. 6-7.

32. The FCC also assigned twenty UHF channels to "educational centers." Sixth Report and Order, 1 Rapro Reg. 91 :601, 619 (1952). Examples of the kind of small communities given a VHF educational reservation and no VHF commercial channel are: Urbana, Ill. (University of Illinois); Lawrence, Kan. (University of Kansas); Orono, Me. (University of Maine) ; State College, Miss. (University of Mississippi) ; Bozeman, Mont. (University of Montana); Chapel Hill, N.C. (University of North Carolina); Vermillion, S.D. (University of South Dakota); and Denton, Tex. (North Texas State College).

33. Cf. id. at 618. Five stations on commercial channels are currently operated by educational institutions in South Bend, Ind.; Ames, Iowa; New Orleans, La.; Columbia, Mo.; and Green Bay, Wis. Jornt Councti on Educational Televiston, Fact Sheet \& Box SCORE 17-19 (Jan. 1958).

In addition, the FCC has recently granted a construction permit for a commercial channel in Mayaguez, P.R., to the Department of Education of Puerto Rico. 16 Radio REG. 113 (1957). The Department plans to devote over $40 \%$ of its time to educational programs. Id. at 147.

A commercial applicant cannot apply for a channel that has been reserved. Hearst Radio, Inc, 9 RADro REG. 145, 149 (1953). He can, however, petition the FCC to delete the reservation in a rule-making proceeding, and apply for it after deletion. See note 43 infra.

34. Sixth Report and Order, 1 Rapro Reg. $91: 601,620$ (1952).

35. Six communities are at present deprived of a second network outlet. Included are Eugene, Ore.; Iowa City, Iowa; and Pueblo, Colo.

Eighteen communities are presently deprived of a third network outlet. Included are 
lishment of a station in every locality was subordinated in those single VHF channel communities denominated "educational centers"; there, establishment of a local station was necessarily postponed until an educational organization was prepared to effect activation. ${ }^{36}$

Since the adoption of the allocations plan, unexpected developments have impaired fulfillment of the Commission's diverse goals. The technically inferior UHF channels have generally failed to support profitable commercial operations, thus causing widespread abandonment of licensed UHF facilities. ${ }^{37}$ At the same time, educational organizations have not activated VHF channels as quickly as commercial broadcasters. Of the eighty-six VHF channels reserved for education in 1952, only thirty-five have been applied for, and many of the remaining channels are in communities which could support more commercial stations than they have been assigned. As a result, numerous commercial operators, financially and technically equipped to commence broadcasting immediately, have petitioned the FCC to delete unactivated educational reservations and allow commercial use of the assignments. ${ }^{38}$ Often, these requests have come from financially distressed UHF licensees to whom a shift of franchise represents the sole prospect of profitable operation..$^{30}$

Viewing its statutory responsibility to insure the most efficient use of broadcasting facilities ${ }^{40}$ in light of these revised circumstances, the FCC has properly reconsidered individual educational reservations in deletion proceedings. Entertainment of deletion requests allows short-run alleviation of the scarcity of broadcasting resources caused by the unforeseen failure of UHF

Dallas, Tex.; Duluth, Minn.; Des Moines, Iowa; Jacksonville, Fla.; Little Rock, Ark.; Las Vegas, Nev.; Savannah, Ga.; and Tulsa, Okla.

Ten communities are presently deprived of a fourth network outlet. They include El Paso, Tex.; Nashville, Tenn.; Portland, Ore.; Phoenix, Ariz.: San Antonio, Tex.; and Spokane, Wash. See 47 C.F.R. $\$ 3.606$ (Supp. 1957).

36. See note 32 supra.

37. Of 37 million television sets in 1956, only about 4 million were equipped to receive $\mathrm{UHF}$ signals. Hearings Before the Senate Committee on Interstate and Foreign Commerce on S. Res. 13 and S. Res. 163, 84th Cong., 2d Sess. 69 (1956). UHF licensees therefore cannot compete in the same market with VHF licensees because they cannot sell sponsors the same audience potential. As of February 12, 1958, there were only 84 commercial UHF stations, compared with 420 commercial VHF stations. BroadcastingTelecasting, Feb. 17, 1958, p. 110.

38. When an educational reservation is deleted, the channel is once again available to all qualified applicants, commercial and noncommercial. Were an educational institution to apply for a deleted channel, it would have to compete with other applicants in a comparative hearing. These hearings are prolonged and expensive. See Schilz, supra note 28 , at 833 .

39. See, e.g., Duluth-Superior Drop-In Case, 15 Radio Reg. 1586 (1956) ; Rib Mountain Television, Inc., 11 RADro REG. 983 (1955); Channel Assignment to Des Moines, Iowa, 14 RADIo REG. 1524d (1956) (same proceeding); Channel Assignment to Weston, W. Va., 14 RAdio Reg. 1586 (1956). A UHF licensee has recently applied for deletion of the reservation in San Antonio, Tex. Jornt Councrl on Educational Television, Fact SHEET \& BOX ScoRe 7 (Feb. 1958).

40. 48 STAT. 1084 (1934), as amended, 47 U.S.C. $\$ 307$ (b) (1952), quoted note 53 infra. 
channels. ${ }^{41}$ Moreover, the threat of deletion has spurred channel activation by educational interests complacent from assurance of permanent reservations. ${ }^{42}$ But while the Commission's decision to entertain deletion requests is proper, its choice of standards is open to criticism.

The deletion process has involved a weighing of community need for an additional commercial outlet against potential educational utilization of the assignment. ${ }^{43}$ Where educational interests have made substantial progress toward station activation, the FCC has consistently rejected deletion requests even though deletion would significantly advance important commercial priorities. ${ }^{44}$ Where little progress has been made, the Commission has also denied deletion if the current need for an additional commercial outlet did not appear sufficient to justify elimination of a possible educational service. ${ }^{45}$ In recent rulings, however, the FCC has laid greater stress upon relative educational

41. "The Commission acted on the belief, held in complete good faith, that the role of the UHF was going to be so important that stations operating in that band would shortly overcome the initial competitive disadvantages facing them." S. Rer. No. 2769, 84th Cong., 2d Sess. 2 (1956) ; see Sixth Report and Order, 1 RAnio REG. 91 :601, 606-08, 661-65 (1952).

42. In Des Moines, Iowa, for example, the local school district filed an application for a construction permit fourteen months after the FCC had taken up the proposal that the VHF reservation be deleted and while a motion for reconsideration of the FCC's denial of this proposal was still pending. Channel Assignment to Des Moines, Iowa, 14 Radro REg. 1524d, 1528a (1956). For discussion of activity in Durham, N.H., San Antonio, Tex. and Denton, Tex., where deletion applications were fled, see Jornt Councti on Educational Telension, Four Years of Progress in Edccational Television 63-64 (1956).

43. Petitions to delete reservations take the form of amendments to the Table of Assignments. Since they concern allocation of facilities and do not make a final grant to any applicant, they are rulc-making instead of licensing proceedings. They are therefore exempt from the formal adjudicatory procedure under the Administrative Procedure Act. 60 Star. 237, 239 (1946), 5 U.S.C. $\$ \$ 1001$ (c)-(e), 1003 (b), 1004(b) (1952). Deletion petitions are usually decided by the FCC solely on the basis of written presentations.

44. See, e.g., Educational Reservation in New Hampshire, 16 Rapro Reg. 1554 (1957); Channel Assignment to Moscow, Idaho, 15 Ripro Reg. 1680 (1957); Channel Assignment to Bozeman-Helena, Mont., 14 Radio Reg. 1595, 1597 (1957); WWEZ Radio, 9 Radio REG. 910 (1953). In the Bozeman-Helena rule making, the reserved educational channel was the only VHF assigned to Bozeman, one of the twenty-six "educational centers." See note 32 supra. Preservation of the reservation meant that Bozeman would be without any local service until educational activation. In the Moscow rule making, the commercial petitioner requested that a commercial VHF outlet be assigned to Moscow. This could have been accomplished by deletion of either the educational reservation at Pullman, Wash. or the commercial channel at Coeur d'Alene, Idaho. The Commission chose to delete the Coeur d'Alene channel, although this choice left the community without a local outlet. Coeur d'Alene did receive, however, three satisfactory services from neighboring Spokane, Wash.

45. Duluth-Superior Drop-In Case, 15 Radio REg. 1643 (1957). To furnish a third commercial VHF, the FCC deleted a channel from two small communities in the area rather then delete the challenged educational reservation. It then rejected the proposal to supply a fourth commercial VHF outlet through deletion on the ground that the need for it did not "justify depriving the educators of the opportunity to fulfill their plans for utilization of the channel." Id. at 1644. In its survey of activities leading to activation of the educational channels, the Joint Council on Educational Television did not report 
progress than upon the community's need for commercial television. Channel Assignment to Bryan-College Station, Texas, established the pattern for these decisions. ${ }^{46}$ There, the community, while possessing no local station, received service from a number of area VHF broadcasters. ${ }^{47}$ No progress had been made toward activating the educational reservation, nor was any expected in the foreseeable future.48 Finding that a commercial station would "provide television service to a substantial number of persons" in the area, the FCC deleted the reservation on petition of a commercial applicant. ${ }^{49}$ The Commission warned educational interests that it could not "justify the continued reservation of available spectrum space for educational purposes . . . in the absence of substantial evidence that the educational interests in a locality have made constructive efforts to fulfill these expectations ... particularly where there is evidence of a demand for the reserved channel for a commercial station which would provide television service to a substantial number of persons."

The $\mathrm{FCC}$ has used this standard in deciding subsequent deletion requests. The formula is vague, and case to case analysis must establish the kind of educational effort deemed "constructive" and the quantum of evidence considered "substantial." The Commission seems most interested in determining the proportion of requisite money and broadcasting equipment which has been raised by educational interests. Of secondary importance is the degree to which the educators have taken the organizational steps necessarily precedent to applying for a station permit. ${ }^{51}$ In considering the merits of a commercial broadcaster's application, the FCC has not specified whether the tele-

activity in Duluth-Superior. JoInt Councti on Educartonal Television, Four Years of Progress in Educatronal Television (1956).

A VHF educational reservation was also preserved to promote competition in an area served entirely by UHF stations by prohibiting entrance of a VHF licensee. Channel Assignment to St. Joseph, Tenn., 15 Radio REG. 1646 (1957).

46. Channel Assignment to Bryan-College Station, Tex., 14 Radio Reg. 1521 (1956).

47. Id. at $1528 \mathrm{~d}$.

48. Id. at 1523 .

49. Ibid. The FCC did not specify whether the "television service" the commercial applicant would give these persons was a first local service or a first adequate network service. Numerous stations located in other cities could be received in the Bryan-College Station area, but the nearest station was sixty miles away. $I d$. at 1528 d.

50. Id. at 1523 .

51. The following showings of progress have been held not "substantial": a "careful study of the growing use of educational television" and a study by a state legisiative commission, four years after reservation of the channel, Channel Assignment to Bryan-College Station, Tex., 14 Radio Reg. 1521 (1956); the purchase of one camera and formation of a faculty committee to plan television activities, Channel Assigument to Weston, W. Va., 14 RADIO REG. 1586 (1956) ; "recently inaugurated studies of the advisability of possible use of the channel in some manner," Channel Assignment to Eugene-Corvallis, Ore., 15 RAdio REg. 1744, 1747 (1957).

The following showings have been considered "substantial": organization of a community foundation and solicitation of $\$ 63,000$ in pledges, WWEZ Radio, 9 Rapro REG. 910,911 (1953) ; purchase of studio equipment and $\$ 35,000$ expenditure on studio facilities, Channel Assignment to Bozeman, Mont., 14 Radio Reg. 1595, 1596 (1957). 
vision service offered to replace the initial educational preference-certainly a first service of some sort as defined by the Bryan-College Station formulamust be a first adequate regional service or may constitute a first local station service as well. ${ }^{\mathrm{b2}}$ A commercial applicant offering a first regional service to a "substantial" number of viewers gives the FCC an opportunity to fulfill, by deleting the reservation, both its foremost commercial priority and its statutory mandate of equitable allocation. ${ }^{53}$ A first local station, on the other hand, performs no such function. Accordingly, a deletion request by a first area service should be more favorably received than one by a first local, and the educational showing required to defeat it should be correspondingly greater.

In one important respect, the Bryan-College Station standard represents a shift from the policies of the original allocation plan. Finding a need for educational stations in the Sixth Report and Order, the FCC assigned reservations to populous communities and educational centers where this need was greatest and could be most effectively met. ${ }^{54}$ But, by stressing educational progress in determining deletion requests, the FCC has de-emphasized consideration of educational need. Thus, in Channel Assignment to Weston, West Virginia, the Byran-College Station standard was applied to delete the only VHF reservation in a state which, because of its low expenditures on education, had a greater need for educational television than most states and was unable to provide the kind of individualized instruction for which educational television substitutes. ${ }^{55}$

In both Weston and Bryan-College Station, the Commission preferred present establishment of a first local commercial station to future development of educational television. If local stations furnished a unique local service, this preference would be justifiable; the public may well derive equal benefit from

52. To judge the adequacy of television service, the FCC recognizes two grades of service, based on the quality of the signal received. The area receives grade $\mathrm{A}$ service when a signal of acceptable quality is received at least $90 \%$ of the time in the best $70 \%$ of the receiver locations at the outer limits of the service area contour. It receives grade $\mathrm{B}$ service when only $50 \%$ of the best receiver locations get adequate signals $90 \%$ of the time. Any reception inferior to this is considered inadequate by the FCC. See 47 C.F.R. \$ 3.683-85 (Supp. 1957) ; Sixth Report and Order, 1 Radro REg. 91 :601, 630 (1952).

53. The Communications Act requires that, in granting licenses, the FCC "shall make such distribution ... among the several States ... as to provide a fair, efficient, and equitable distribution of radio service to each of the same." 48 STAT. 1084 (1934), as amended, 47 U.S.C. $\S 307$ (b) (1952). In effectuating this statutory policy, the Commission designated as its first allocation priority furnishing some form of television service to every area of the country. See note 34 supra and accompanying text.

54. Sixth Report and Order, 1 Radio Reg. 91 :601, 612 (1952).

55. Channel Assignment to Weston, W. Va., 14 Radio Reg. 1586 (1956). Weston had been assigned an educational VHF outlet as an "educational center." A neighboring community, Clarksburg, W. Va., had been assigned a commercial VHF channel, which was the subject of a comparative hearing at the time of the Commission's decision in Weston. The FCC found that many television homes in the Weston market depended for the reception of signals from the nearest operating commercial station upon "community antenna" systems, which are powerful enough to pick up signals from transmitters too distant to be received by ordinary home antennas. But some towns in the Weston market had no 
a commercial station catering to local needs and a station concentrating primarily on educational presentations. But the typical commercial station is "local" in name only. The bulk of its service consists of programs unrelated to community events and originating far from the locality. ${ }^{50}$ If viewers can receive network or film programs from a station located in a neighboring community, a local station, under normal circumstances, would not seem to offer the public a service sufficiently unique to justify elimination of a potential educational outlet.

Nor does the Commission's effort to minimize the effects of deletion by substituting a UHF educational reservation for the VHF reservation deleted affect this conclusion. The practice assumes that UHF outlets will be capable of effective broadcasting by the time educators are prepared to activate a station. ${ }^{57}$ But this assumption is not necessarily accurate. UHF broadcasting may not be sufficiently developed to compete adequately with VHF channels for many years. ${ }^{5 s}$ Consequently, the present substitution policy can only tend

community antenna systems and were receiving no television service at all. The FCC thu based its deletion not only on lack of educational progress, but on a finding of a "present lack of adequate television service in the Weston area at this time." Id. at 1590 . While a total lack of service would usually be sufficient reason for a deletion, see note 53 supra and accompanying text, the lack in this case was attributable to the FCC's own delay in processing the Clarksburg VHF applications.

West Virginia stands forty-first among the states in educational expenditures per student. A recent survey of education in the state showed numerous educational deficiencies, including a lag in scholastic achievement behind the national norm at all levels and a decline in enrollment in basic scientific and social science subjects. Time, Jan. 20, 1958, p. 73.

For nondeletion decisions in which educational need has been considered by the FCC, see John H. Phipps, 11 Rapro Reg. 1527, 1530b (1954) (commercial channel reserved for educational use because need for educational television was found). Where an educational institution applied for a commercial channel in a comparative hearing, the FCC stressed educational need. Sucesion Luis Pirallo-Castellanos, 16 Ranio Reg. 113, 131 (1957): "The Department [of Education of Puerto Rico] presented statistical and other evidence from reliable sources which strongly indicates that a high percentage of illiteracy and extremely low educational levels prevail among the inhabitants of various age groups residing in the ... area and that attendance at the public schools therein has been greatly restricted due to shortage of teachers and classroom facilities." Id. at 149.

56. Television stations have been unable to operate successfully with a high proportion of local programming. Second Report on Deintermixture, 13 RaDio REg. 1571, 1574 (1956). Most television stations affiliate with national television networks. A recent survey of the programming of 132 network-affiliated stations showed that only $15.6 \%$ of their broadcast time was devoted to local live programs. The rest was devoted to network: programs, film and other outside material. Broadcasting-Telecasting, April 2, 1956, $\mathrm{pl}$. 78-80.

For elaboration of the view that only stations denied network affiliation have the incentive to produce extensive local programming, see Testimony of Richard A. Moore, 4 Hearings Before the Senate Committee on Interstate and Foreign Commerce Pursuant to S. Res. 13 and S. Res. 163, 84th Cong., 2d Sess. 1477 (1956).

57. See FCC ANn. Rep. 102 (1956). But cf. Channel Assignment to Eugene-Corvallis, Ore., 15 RADIo REG. 1744 (1957) (VHF reservation deleted, no UHF reservation substituted).

58. Effective competition will require both technical improvement of the UHF band and elimination of the present scarcity of UHF-adaptable receivers. To accomplish the 
to postpone important educational efforts toward activation until UHF broadcasting becomes feasible. At that time, moreover, educators may face a new challenge from commercial broadcasters. New uses of television facilities may create a demand for UHF outlets comparable to the present demand for VHF channels. ${ }^{.09}$

In considering future deletion requests, the FCC should give appropriate consideration to all elements affecting the public interest. The need for educational television in the area, and the educators' capacity to satisfy that need, must be balanced against the benefits expected to result from an additional commercial outlet. Where educational television is especially important to the surrounding communities, as in Weston, a permanent lack of commercial service should be required to justify deletion even absent current educational progress. Similarly, where viewers receive competitive service from the three major networks, the FCC should maintain the reservations unless convinced that educational activation is impossible within the predicted period of UHF inadequacy, or unless the commercial applicant offers substantial and unique local programming service. The weighing process becomes more difficult, however, if viewers are unable to receive competitive network service either from local or neighboring stations. To keep their reservation in such a situation, educational interests should be required to show financial and organizational ability to activate their assignments within the reasonably near future.

\section{Organization of Educational Stations}

Organizations formed to own and operate educational television outlets are governed both by regulations of the FCC and by state statutes. To insure sufficient educational emphasis in station management and programming, federal regulations prescribe the nature of organizations allowed to hold educational licenses. ${ }^{60}$ State statutes, founded on the state reserve power over education, ${ }^{61}$ delimit the television activity of public educational institutions and, under some

first, the FCC has encouraged the television industry to embark on an extensive program of research and development, aimed at increasing the range and reducing the imperfections of UHF signals. Second Report on Deintermixture, 13 Radio REG. 1571, 1578 (1956). It has also increased the maximum permissible power of UHF transmitters from 1000 to 5000 kilowatts. Id. at $158 \mathrm{~s}$. To get more UHF sets into the hands of the public, it has been suggested that the excise tax on all-channel television sets be removed. This would equalize their cost with that of VHF-only sets. Hearings, supra note 56, at 70.

59. Developing uses for television channels include film stations, BroadcastingTelecasting, June 10,1957 , p. 59 ; id. June 24,1957 , p. 16 , toll television, a system by which viewers instead of advertisers pay for desired programs, First Report on Subscription Television, 16 Rano REG. 1509 (1957) ; Broadcasting-Telecasting, Aug. 26, 1957, pp. 3235, and nonnetwork special program services, $i d$. April 15, 1957, pp. 31-32.

In addition, portions of the broadcast spectrum can be diverted at any time for governmental uses by order of the President of the United States, whose statutory authority over governmental stations supersedes that of the FCC. 48 Srat. 1083 (1934), as amended, 47 U.S.C. $\$ 305$ (a) (1952). For a report on current requests for VHF channels for military uses, see Broadcasting-Telecasting, April 1, 1957, pp. 31-32.

60. See notes 63-67 infra and accompanying text. 
circumstances, designate the conduct of private educational institutions as well. ${ }^{62}$

The FCC will license only nonprofit-making educational organizations to operate educational television stations. ${ }^{63}$ Among public instrumentalities presently licensed are school systems, state universities and state commissions specifically created for the purpose ; private licensees include nonprofit corporations and foundations. ${ }^{64}$ The FCC has not attempted to refine the meaning of "educational organizations." Yet the tenor of the regulations-requisites are discussed exclusively in terms of academic institutions ${ }^{65}$-and the enabling requirement that a station be used primarily to serve the educational needs of the community suggest an intent to limit licensees to institutions formed for predominantly educational purposes. ${ }^{68}$ Generally, nonprofit groups not so constituted have neither the expertise nor the incentive to concentrate broadcasting exclusively on educational subject matter. And to allow a noneducational organization-such as a hospital or charity-to use reserved facilities for its own purposes would change the design of the reservations. However, the FCC has accepted as "educational organizations" corporations formed solely for the purpose of operating educational stations. Since these corporations are formed by constituent groups, a noneducational organization desiring to participate in the management of an educational station could circumvent the limitation by joining with other bodies-educational or noneducational-to form a single-purpose educational licensee. Conceivably, profit-making organizations could avoid the regulations in the same manner. Such formalism should not be permitted. The FCC considers noneducational as well as profit-making organizations incapable of effectuating desired educational goals. To assure full implementation of this policy, it should look to the component parts of any single-purpose applicant and require that each be primarily educational and nonprofit. ${ }^{67}$

61. For a discussion of the state police power over education, see Edwards, THE Courts AND THE PUBlic Schools 5-7, 23-24 (1933).

62. See notes 68-75 infra and accompanying text.

63. "[N]on-commercial educational broadcast stations will be licensed only to nonprofit educational organizations upon a showing that the proposed stations will be used primarily to serve the educational needs of the community; for the advancement of educational programs; and to furnish a nonprofit and noncommercial broadcast service." 47 C.F.R. $\$ 3.621$ (a) (Supp. 1957).

64. Of the 20 publicly owned stations now operating, 7 are licensed to departments of education and local school boards, 8 to state universities, 4 to state commissions and 1 jointly to a university and a school district. Of the 10 privately owned stations, 4 are licensed to foundations and 6 to community corporations and unincorporated associations. Jornt Council on Educational Television, Fact Sheet \& Box Score 2-16 (Jan. 1958).

65. 47 C.F.R. $\$ \$ 3.621$ (a) (1), (2) (Supp. 1957).

66. See note 63 supra.

67. Constituent groups of the ownership organizations of stations currently operating have some sort of cultural, scientific, historical or other educational orientation. The membership of the Chicago Educational Television Association includes colleges, museums, the Art Institute, libraries, the Zoological Society and the Board of Education. The Greater 
The organization of educational television stations has also been significantly influenced by local regulation. Enacted prior to development of the medium, state legislation defining the powers of school authorities generally does not contemplate the specific requirements of educational television. Thus, absent special statutory authorization, public educational bodies are often barred from television activity, since, as quasi-municipal bodies, their powers are strictly construed. ${ }^{\text {s8 }}$ Legislation authorizing educational broadcasting has taken various forms. The most common type of statute broadly authorizes educational authorities to construct and operate television stations. ${ }^{69}$ A more limited form of legislation, in force in Illinois and California, allows school boards to purchase programs and offer financial and production assistance to stations but specifically forbids station operation. ${ }^{70}$ Ohio recognizes school-board contribution to private, nonprofit educational television corporations. ${ }^{71}$ In contrast to Illinois and California, however, this express grant of power need not imply a prohibition against school-board ownership of stations. Additionally, six states have created state commissions to regulate educational broadcasting, with authority ranging from researching and advising to actual ownership. ${ }^{\mathbf{2}}$

Cincinnati Educational Television Foundation is composed entirely of school systems and educational organizations. The WGBH Educational Foundation in Boston is composed of representatives of two universities, two foundations, an orchestra and the Lowell Institute Cooperative Broadcasting Council. Membership in the Detroit Educational Television Foundation includes public and parochial schools, colleges, museums, a library and an orchestra. QUEstTonNaIREs.

68. 16 McQuillin, Municipal Corporations $\$ \$ 46.02-03$ (3d ed. 1950). For examples of restrictions, see letter from the Assistant Attorney General of California to the State Department of Education, Dec. 10, 1952, on file in Yale Law Library: "[W] hile we recognize television as a potential force in education, it is obvious that none of the provisions of the Education Code, or of any other statutes of the state, were enacted with the idea that school districts or county superintendents of schools would engage in or spend public funds on the proposed activity ...." See also State of Calrfornia, LeGrslattive Counsel Op. No. 10945 (May 26, 1953). Cf. Turkevich v. Board of Trustees, 11 III. $2 \mathrm{~d} 460,143$ N.E.2d 229 (1957), where the broad grant of authority to a state university to provide facilities required to teach "branches of learning" in "the most thorough manner" was held to include the authority to own and operate a television station.

Privately owned television stations, while not subject to these restrictions, may find their attempts to broadcast public school instructional programs in return for school financial contributions blocked by laws prohibiting state financial aid to nonpublic educational institutions. See, e.g., MAss. Const. art. XLVI, $\$ 2$ id. art. LXII, $\S 1$.

69. Fla. Sess. Laws 1957, c. 57-312, § 246.08; N.Y. Sess. Laws 1954, c. 201, § 1; N.Y. Enuc. Law $\$ 236$; La. Rev. Stat. ANn. $\$ \$ 17: 2751-: 2753$ (Supp. 1957) ; Pa. Stat. Ann. tit. 24, \$ 5-523 (Supp. 1957); Tenn. Code Ann. § 49-3801 (Supp. 1957).

70. Cal. Educ. Code $\$ \$ 9551,20255$; Irl. Ann. Stat. c. 122, §§ 6-60, 34-17(10) (SmithHurd Supp. 1957).

71. Onlo Rev. Code Ann. $\$ 3317.16$ (Page Supp. 1957).

72. AlA. Cone tit. 52, \$\$ 627-32 (Supp. 1955) (ownership); Fla. Sess. Laws 1957, c. 57-312, $\$ \$ 246.01-14$ (co-ordination and assistance; leasing or operation of transmission facilities); LA. Rev. Stat. ANN. \$§ 17:2501-:2508 (Supp. 1957) (financial aid, research and publicity); N.C. Gen. Stat. \$§ 143-273 to -276 (Supp. 1952) (survey); Okta. Stat. Ann. tit. 70, $\$ \$$ 
To facilitate development of statewide educational networks, some states have adopted statutes which concentrate ownership of all domestic educational stations in a single state instrumentality. Alabama has delegated to the local Television Commission control over the use of reserved channels located within the state; Oklahoma's Commission is empowered to own and operate all domestic outlets. ${ }^{73}$ In effect, these statutes, barring private organizations from participating in educational broadcasting, create a state monopoly over educational television. Conflict between them and the FCC's statutory power of choice among applicants could arise when an otherwise qualified private organization sought an educational channel. ${ }^{74}$ Moreover, the $\mathrm{FCC}$ has indicated that it would consider competing applications from private and public educational organizations. ${ }^{\text {T5 }}$

In direct collision with federal regulation under the commerce clause-the

2145-59 (Supp. 1957) (ownership) ; TENN. CODE ANN. \$\$ 49-3802 to -3805 (Supp. 1957) (financial aid and research); WIs. StAT. $\$ 43.60$ (1955) (research and experiments).

73. Ala. Code tit. 52, $\$ 631$ (2) (Supp. 1955) ; OKLa. Stat. Ann. tit. 70, $\$ \$ 2146$ (a), (f) (Supp. 1957). New York gives its Board of Regents "the duty and responsibility of supervising the organization and operation of non-profit, noncommercial educational television corporations in the state." N.Y. Sess. Laws 1954 , c. $201, \S 1$. This provision must be read in connection with another allowing the Regents to grant articles of incorporation to "any group, institution or association for the purpose of constructing, owning, operating or maintaining a non-profit and noncommercial educational television station or for providing educational television programs." N.Y. EDuc. LAw $\$ 236$. Although the Regents thus has considerable supervisory power over stations operated by such corporations, the statutes do not require public ownership. Alabama and Oklahoma do. Moreover, a private educational group in New York not organized as' an educational corporation apparently could own a station without Regents approval, since the Regents' authority is limited to such corporations.

The bylaws of the Alabama Educational Television Authority provide that its authority is subject to the rules and regulations of the FCC.

74. These bodies might include private and parochial schools or school systems, private colleges and universities, community organizations formed for the purpose of adult education and educational foundations.

75. "[T] $]$ he question of diversification of control of FM noncommercial educational stations is ... pertinent in cases where there are competitive applications for such stations by qualified educational applicants." State of Wisconsin Radio Council, 7 Radro REG. 968 (1952). Although the issue in this case concerned assignment of educational FM reservations, the policy is equally applicable to television, since the bases of assignment of both media are the same. In judging educational FM applications, the FCC will consider the extent to which an applicant fits into a state network plan. However, it will not allow the presentation of a network plan by a state to displace its own judgment on the state's educational needs. In deciding whether to select an applicant which is part of such a plan, the FCC will consider whether the plan, among other things, affords "fair treatment to public and private educational institutions, urban and rural, at the primary, secondary, higher and adult educational levels." 47 C.F.R. $§ 3.502$ (Supp. 1957). Presumably, this approach would apply as well to television networks. To allow the state to own all channels in appropriate instances, the FCC has exempted educational television stations from the operation of the multiple ownership rules which forbid a single owner to control more than one station in the same primary service area, or more than seven in the nation. Id. $\$$ 3.636 (b). 
constitutional basis for the Communications Act ${ }^{76}$ - state monopoly statutes must bow. Traditionally, federal legislation fully occupying a field of commerce has precluded state participation. ${ }^{77}$ In the broadcasting field, which Congress has fully occupied by the Communications Act, state attempts to license or tax stations, or to censor material prepared for broadcast within the state, have already been nullified. ${ }^{78}$ And while the reserve authority over education is often regarded as one of the most sacrosanct of the police powers, ${ }^{70}$ state educational legislation interfering with a federal regulatory scheme should be equally invalid. Admittedly, state legislation limiting potential applicants to state instrumentalities would not force the FCC to countermand its statutory mandate; the Commission could refuse to license even a lone state applicant if licensing were thought contrary to the public interest. By confining the FCC's range of choice, however, such legislation does interfere with maximum utilization of broadcast facilities. For this reason, the fatal conflict with the Communications Act exists.

State monopoly statutes may also be subject to attack as illegally impairing the ability of private schools to educate their students. The plenary power of a state to educate its citizens includes a broad supervisory power over private educational institutions. ${ }^{80}$ But the exercise of this power is limited by the school's constitutional guarantees of liberty and property and the concurrent right of parents reasonably to direct the education of their children by sending them to qualified private schools of their choice. ${ }^{81}$ At the present

76. U.S. Const. art. I, $\S 8$, cl. 3. The Communications Act was passed "for the purpose of regulating interstate and foreign commerce in communication by wire and radio." 4S Stat. 1064 (1934), as amended, 47 U.S.C. $\$ 151$ (1952).

77. See, c.g., Cloverleaf Butter Co. v. Patterson, 315 U.S. 148 (1942); Hines v. Davidowitz, 312 U.S. 52 (1941). See Note, "Occupation of the Field" in Conmerce Clause Cases, 1936-1946: Ten Years of Federalism, 60 HARv. L. Rev. 262 (1946) ; Grant, The Scope and Nature of Concurrent Power, 34 Colvar. L. Rev. 995, 1019 (1934).

78. Fisher's Blend Station, Inc. v. State Tax Comm'n, 297 U.S. 650 (1936) (tax); Whitmore v. Bureau of Revenue, 64 F. Supp. 911 (D.N.M. 1946) (tax and license fees); Tampa Times Co. v. Burnett, 45 F. Supp. 166 (S.D. Fla. 1942) (tax) ; NBC v. Board of Pub. Util. Comm'rs, 25 F. Supp. 761 (D.N.J. 1938) (license).

Dumont Laboratories v. Carroll, 184 F.2d 153 (3d Cir. 1950), cert. denied, 340 U.S. 929 (1951), involved an attempt by the Pennsylvania State Board of Censors, acting under the state police power, to screen the content of motion pictures shown on television. Their power to censor motion pictures shown in theaters was admitted. The court avoided the censorship issue and based its decision on its belief that "Congress has occupied fully the field of television regulation, and ... that field is no longer open to the States." Id. at 156.

79. Cf. Merrill, The Function of the States Today-A Tentatize Bheprint for Federalism in Trenticth Century Amcrica, 30 Iowa L. Rev. 169, 178 (1945).

80. See, c.g., Edwards, The Courts and the Public Schools 22 (1933).

81. Pierce v. Society of Sisters, 268 U.S. 510 (1925). An Oregon act requiring children to attend public schools was held an unconstitutional exercise of the police power on the grounds that it deprived private and parochial schools of their property without due process of law and that it abridged the freedom of parents and guardians to provide for a child's education. Id. at 535 . 
time, an argument based on these limitations would most likely fail, for courts have not applied them to state action affecting activities unnecessary to a private school's existence-a category apparently embracing the operation of an educational station. However, in the future, the importance of educational television as a teaching device may significantly increase. At that time, state restrictions may more closely approach the prohibited area embraced by the Fourteenth Amendment.

The choice between state and private applicants should be made entirely by the FCC, after comparing the financial and technical capacity of each aspirant and considering the relation between proposed program services and local needs. A state network may be a suitable licensee in states with small populations or in which the major educational institutions are publicly owned. Recognition of public monopoly statutes in more populous states, however, would greatly restrict the choice of qualified licensees. ${ }^{82}$ More generally, to the extent that publicly owned stations tend to place more emphasis on inschool than adult education, state monopoly would also conflict with the FCC's desire to promote both facets of programming. ${ }^{83}$

\section{Financing}

Limited financial resources present the greatest current barrier to the maximum development of educational television. Both in outlet activation and programming, lack of funds has impaired most effective utilization of the medium's potential. Reserved channels in many communities remain idle since educators are unable to raise funds necessary to commence operation. ${ }^{34}$

82. See note 74 supra. Educational institutions owning commercial television stations include Notre Dame and Loyola Universities, and St. Norbert College, Green Bay, Wis. Joint Council on Educational Television, Fact Sheet \& Box Score 17-19 (Jan. 1958).

83. Cf. Sixth Report and Order, 1 Radio REg. 91 :601, 612 (1952).

84. See note 51 supra and accompanying text. The difficulty of raising funds has been discussed by the FCC in the following deletion proceedings: Channel Assignment to Des Moines, Iowa, 14 Radro Reg. 1524d, 1526, 1528d (1956) ; Educational Reservation in New Hampshire, 16 Radio REg. 1554d, 1557 (1957). In Gainesville, Fla., an application for a construction permit had to be withdrawn pending appropriation of additional funds to finance the station. Jonnt Council on Educational Terevision, Four Years of ProGRess IN Educatronal Television 55 (1956). In the earliest years of the reservations, the FCC granted construction permits to educational organizations even though they could make no showing of financial ability to activate the channel. Some of these are still outstanding, because funds remain unavailable. See Board of Regents of the University of the State of New York, 8 Radio REG. 134a (1952) (seven permits granted, none yet activated); Kansas State College, 8 Ratro REc. 133 (1952). These grants were accompanied by waiver of the regulation that the permit expires unless construction begins within sixty days after its issuance. For the regulations, see 47 C.F.R. $\$ \$ 3.626-627$ (Supp. 1957).

The FCC now requires public educational applicants to state "full information as to the sources of funds for the construction of [the] station, including whether such funds have been authorized, appropriated or how they will otherwise be made available." Application for Authority to Construct a New Broadcast Station or Make Changes in an Existing Broadcast Station, 1 Radro REG. 98:101, 108 (1954). 
Similarly, operating stations cannot independently finance the type of broadcasts which would make the most effective use of television as an educational tool. ${ }^{85}$

This lack of resources results from educational television's inability to tap the primary source of revenue available to commercial stations, the sale of time to sponsors. The FCC prohibits educational stations from broadcasting any program for which "a consideration is received." 80 Exceptions to this general rule allow the broadcast of recorded programs furnished by outside sources or the receipt of the actual cost of program production if it constitutes the only consideration flowing to the station. ${ }^{87}$ Under special restrictions regarding commercial announcements, educational stations may also broadcast programs originally produced on commercial outlets when the commercial station or network pays the necessary transmission charges. ${ }^{88}$ These ex-

85. Financial limitations impede both the extent and the quality of the programming. The annual operating budgets of many educational stations-between $\$ 300,000$ and $\$ 400,000$ -are less than the cost of one network "spectacular" program. Hale, $A$ Legacy From the Model T to the Age of ETV, The Reporter, May 30, 1957, pp. 10, 12. In 1957, the average educational station broadcast 31 hours a week, or about $4 \mathrm{r} / 2$ hours a day. The largest number of hours broadcast by any station in one week was 72 , the smallest $121 / 2$. N.Y. Times, Jan. 19, 1958, § 5, p. 11, col. 1. Commercial stations must broadcast a minimum number of hours each week. Educational stations are exempt from this requirement, but the FCC will consider their actual performance in considering renewal applications. 47 C.F.R. $\S \S$ 3.651 (a), (b) (Supp. 1957).

86. Id. \$ $3.621(\mathrm{~d})$.

87. Ibid. This regulation is vague. It stipulates that the station can receive no other consideration than the "furnishing of the program," but does not define a "furnishing." The exception for "programs produced by or at the expense of or furnished by others than the licensee" seems to indicate that furnishings are limited to the actual program (prepared for broadcast) or the expenses of producing a program. This interpretation is supported by $\$ 3.654$ (d), which differentiates "furnished" from "paid for" or "sponsored." This narrow interpretation of "furnished" would seem to preclude outside organizations from paying for those costs of broadcasting a program which are not normally included as part of the cost of production: transmission costs, pickup costs, studio employee costs, recording and editing costs (if the program is not broadcast live), and those maintenance and depreciation costs attributable to the program. Thus, if a school system wished to televise a play from a school auditorium, it could not pay the station the costs of making the remote pickup or of transmitting the program to viewers' sets.

If an organization desires to furnish a program for broadcast on an educational station, it should be able to pay all the costs directly chargeable to the broadcast, not just the production charges. Section 3.621 (d) should be clarified accordingly.

88. "(d) An educational station may not broadcast programs for which a consideration is received, except programs produced by or at the expense of or furnished by others than the licensee for which no other consideration than the furnishing of the program is received by the licensee. The payment of line charges by another station or network shall not be considered as being prohibited by this paragraph.

"(e) To the extent applicable to programs broadcast by a noncommercial educational station produced by or at the expense of or furnished by others than the licensee of said station, the provisions of $\S 3.654$ relating to announcements regarding sponsored programs shall be applicable, except that no announcements (visual or aural) promoting the sale of a product or service shall be transmitted in connection with any program: 
ceptions were created to allow educational stations to carry programs they themselves were incapable of producing.

The prohibition against sale of time has forced educational stations to rely upon alternative sources of financial aid. Some operate exclusively with state funds. Others receive grants from schools and nonprofit foundations. A number of stations, especially those which are "community-owned," accept contributions both of money and of programming assistance from school systems, community service organizations, business groups and private individuals. ${ }^{89}$ However, the flow of revenues from all these sources suffers from the general public reluctance to finance educational projects.90

Some educational stations have supplemented revenues through financing arrangements with business institutions. These arrangements include on-theair acknowledgement of contributions of money or equipment, "credit" announcements to firms which furnish programs or pay production costs, and the broadcast of programs which, while carrying no specific commercials, influence audiences to purchase particular products. ${ }^{91}$ By donating money or

Provided, however, That where a sponsor's name or product appears on the visual inage during the course of a simultaneous or rebroadcast program either on the backdrop or in similar form, the portions of the program showing such information need not be deleted." Id. $\$ \$ 3.621(\mathrm{~d})$, (e).

An application by an educational station for a waiver of this requirement to enable it to broadcast network coverage of the national political conventions (deletion of the commercials not being practicable) was denied by the FCC. Metropolitan Pittsburgh Educ. Television Station (WQED), 14 Rabro REg. 149 (1956).

89. Questionnarres. The Joint Council on Educational Television estimates that in the years 1953-57 sixty million dollars were spent on educational television activities. The sources of this sum were as follows:

\begin{tabular}{lr} 
Foundations & $\$ 28,000,000$ \\
State Legislatures & $\$ 7,000,000$ \\
Public Universities & $\$ 7,000,000$ \\
Miscellaneous Private Organizations & $\$ 7,000,000$ \\
\multicolumn{1}{c}{$\quad$ (including business firms) } & \\
Commercial Broadcasters & $\$ 6,000,000$ \\
Municipal Governments and Boards of Education $\$ 5,000,000$
\end{tabular}

Joint Council on Educatronal Televiston, Fact Sheet \& Box Score 1 (Jan. 1958).

90. A bill to provide federal grants-in-aid to states for educational television, S. 2119, 85th Cong., 1st Sess. (1957), has been pigeonholed in the Senate Interstate and Foreign Commerce Committee since May 17, 1957. Under its provisions, a state which had secured authorization from the FCC for the acquisition or installation of television broadcasting facilities could apply to the United States Commissioner of Education for a grant to finance the establishment of these facilities. The Commissioner could grant each applicant state up to $\$ 1,000,000$ from funds appropriated by Congress. Private or communityowned stations would not be eligible for grants, since the bill provides that the state must assure the Commissioner that "the operation of such facilities will be under the control of the State agency or officer primarily responsible for the State supervision of public elementary and secondary schools." Id. § 2 (b) (2).

91. Questronnaires. These programs may have an educational as well as commercial value. Examples include: a series of programs on how to play the piano, paid for by local music stores; programs on how to invest in securities, paid for by local brokerage 
furnishing programs in return for "credits," a sponsor may keep his name favorably before the public. And "silent commercials," inherent in programs creating an appetite for specific products, are an even more direct selling device. ${ }^{.2}$

In justification, educational stations argue that these practices, involving no consideration to the station other than the program itself, do not constitute a prohibited commercial relationship. Moreover, they stress the regulations' express requirement that the source of donated programs be identified. ${ }^{93}$ However, these commercial arrangements were not contemplated by the regulations which, on their face, seem to sanction or require them. The compulsory identification of program suppliers was written not to allow goodwill advertising but to prevent hidden advertising by identifying for the public the source of paid broadcasts. ${ }^{94}$ Again, the allowance of programs furnished by others than the licensee was designed to help educational stations augment their programming without resort to commercial sponsorship.

Although these practices do not contravene the FCC prohibition against "sale of time," they create the same basic commercial relationship between station and sponsor which that prohibition was designed to prevent. In each instance, the seller receives revenue or services as consideration for furnishing

institutions; and health education programs, financed by a grant from a life insurance company. In the case of the piano-lesson programs, merchants who financed the programs claimed that consumer demand for their product increased. Wall Street Journal, Jan. 8. 1957, p. 1, col. 4.

92. They are so regarded by the firms which furnish them. See ibid.

93. "In the case of any program, other than a program advertising commercial products or services, which is sponsored, paid for or furnished, either in whole or in part . . by a corporation, conmittee, association or unincorporated group, the announcement ... shall disclase the name of such corporation, committee, association or other unincorporated group." 47 C.F.R. \& 3.654(d) (Supp. 1957). Educational stations are specifically made subject to this regulation. Id. \$ $3.621(\mathrm{e})$.

94. Section 3.654 was written to implement $\$ 317$ of the Communications Act. 48 STAT. 1089 (1934), 47 U.S.C. $§ 317$ (1952). This section was derived, without change, from the Radio Act of 1927, c. $169, \S 19,44$ Stat. 1170. According to the committee report on the Radio Act, the purpose of the section was "to make sure that advertising shall not be hidden from the listener." H.R. REP. No. 404, 69th Cong., 1st Sess. (1926). The kinds of disguised advertising the statute was aimed at were illustrated by Representative Celler in a speech to the House of Representatives, 67 CoNG. REc. 5488 (1926), as follows: "This is SPOOF station, Chicago, Ill. You have just listened to Mr. B. Fuddled, of the Lone Star Ham Co., in his interesting talk on "Tid-bits and why delicious Lone Star ham should be on every table.'

"Those of you who relish. a good cigar will be delighted to hear that our next number will be a song, 'Rings of Smoke,' to be rendered by Mr. Jack A. Napes, general sales manager of the Amalgamated Cigar Stores Co. We ask our radio fans to remember the Amalgamated Cigar Stores Co., because it will have one of its employees perform for us every Monday night.

"This is KOKO station. Doctor Bunkum's Sanitarium of Cripple Creek, Mich., Doctor Bunkum announcing. Folks will receive with interest the news that $I$ shall lecture on 'My Pink Pills for Pale People.' I shall be pleased to see any nervous, anemic person and show how to build him up with 'Pink Pills for Pale People.'" 
the buyer with an opportunity to influence consumer behavior. No practical difference exists between charging for program costs and selling time, except that the latter charge includes a margin of profit. Where donations or programs are exchanged for the equivalent of goodwill advertising, commercial firms obtain a benefit comparable to that received for similar advertising on commercial outlets. ${ }^{95}$ Where the program itself is in the nature of a "silent commercial," the analogy to sale of time is equally obvious. Nevertheless, so long as the regulations allow such quasi-commercial practices, they may be expected to increase. For commercial advertising money is more freely available to broadcasters than gratuitous contributions or government funds. ${ }^{96}$

In light of the potential expansion of such commercial relationships, the basic prohibition against sale of time by educational stations should be re-examined to determine whether its purifying effect on program content is worth its restrictive effect on available funds. Either the sale of time should be allowed or the regulations should be amended to prevent deviation from commission intent. The arguments favoring sale of time stem from the premise that station revenues would be significantly increased. Additional funds would allow activation of idle reservations; with the creation of new outlets and more diversified networks, ${ }^{97}$ the quality and scope of programs actually broadcast would also increase. The beneficial effects of enhanced educational revenues, moreover, would not be limited to educational broadcasting alone. Improvements in that segment would stimulate competitive conditions in the television industry as a whole; all broadcasters would seek to better their service in order to compete more effectively for audiences and sponsors.

Were educational stations allowed to sell time, however, they might still be unable to increase operating funds. Commercial revenues might not be as great as anticipated. Educational stations possess an initial competitive advantage in the race for sponsors, since they can set rates which include neither a profit margin nor a provision for taxes. But this cost advantage might be more than offset by education's inability to offer sponsors as large an audience or as flexible a programming schedule as commercial outlets. Furthermore, if educational stations were allowed to sell time, the rationale of the reservations policy would lose its meaning. The educational character of the stations was not the basis of this policy; educational institutions which desire to sell time may

95. That institutional and goodwill advertising can have a commercial value to business firms has been recognized by the Treasury, which allows amounts expended for such advertising to be deducted from gross income as an "ordinary and necessary" expense of business. See Rev. Rul. 1942-28-11150, 1942-2 Cum. Bull. 87; Rev. Rul. 1942-42-11213, 1942-2 Cum. Bulz. 88.

96. See note 90 supra.

97. One suggestion, advanced by the former president of NBC, Sylvester Weaver, would use educational stations and stations not affiliated with networks as local outlets for "program service" which would produce classics, news and information projects and other "high-level" shows that appeal to limited instead of mass audiences. Sponsors would ostensibly be drawn from those who cater to a "quality" market. See BroadcastingTelecasting, April 15, 1957, pp. 31-32. 
broadcast on unreserved channels. Rather, the FCC reserved channels in the belief that educational institutions would need more time to raise funds than would stations which had access to advertising revenue. ${ }^{98}$ Allowing educational institutions to secure such revenue would destroy this justification.

More serious is the effect of sale of time on the basic educational purpose of the stations. Stations dependent upon commercial revenue are necessarily in competition for sponsors with other stations and with other mass media. Sponsors naturally favor media offering access to the largest audience at the lowest unit cost. ${ }^{99}$ Thus, television stations which sell time must strive to maximize the sponsor's potential economic reward by producing programs capable of attracting large audiences and holding them for the commercial announcement. The potential audience for the most useful educational programs, however, is far more limited than that of the typical commercial show. ${ }^{100}$ To the extent that educational stations competed for revenue from the sale of time to sponsors, therefore, they would confront the alternatives of competitive

98. See Third Notice of Further Proposed Rulemaking, 16 FED. REg. 3072, 3080 (1951).

99. The value of advertising depends on the cost of the program, the number of homes it reaches and its effectiveness in producing sales. The last of these factors is difficult to determine. But the second can be estimated from "ratings" which measure the program's audience. An advertiser wants to get the largest audience, and thus the greatest sales potential, for each dollar spent. In broadcasting, this standard is expressed as a "cost per thousand" circulation, which is the rate charged by the station divided by the number of homes (in terms of thousands) with television sets tuned in to the program. The lower the cost per thousand, the better bargain a program becomes to a sponsor.

Where the sponsor is interested in reaching a special audience instead of a mass audience, or when he is advertising only for prestige purposes, the factor of cost per thousand hecomes less important. See, generally, CBS, Network Practices 56-67, printed in Hearings Bcfore the Senate Committee on Interstate and Foreign Commerce on S. Res. 13 and S. Res. 163, 84th Cong., 2d Sess., pt. 4, at 1758-69 (1956).

100. The following schedule for WGBH-TV, Boston, for Tuesday, October 30, 1956, typifies the programming of educational stations specializing in more extensive projects: 6:15 The Friendly Giant. (children's show) Bob Homme, University of Wisconsin School of Music.

6:30 Louis M. Lyons and The News. Curator of the Nieman Fellowships, Harvard University.

6:45 The Worln We WANr. Foreign high school students discuss world problems.

7:15 Neighror to the NoRth. Film portraits of Canadian life.

7:30 Passing Nores on Music. Gomer J. Jones, Professor of Music, Michigan State University.

8:00 The Canspaign Issues. Louis $M$. Lyons and guests.

3:15 Boston Symphony Orchestra. Charles Munch, Music Director. (From Kresge Auditorium, Harvard University.)

8:30 Books and Ideas. World Enough and Time, by Robert Penn Warren.

9:00 Laboratory. Experiments in ideas and techniques. Poetry of Edward Lear. David McCord, Honorary Curator of the Farnsworth and Poetry Rooms in the Harvard College Library.

Joint Council on Ejucational Television, Four Years of Progress in Educational TELEVISION 129 (1956). 
failure or a thoroughgoing adjustment of the program service for which they had been licensed. The ensuing program revision could only detract from the educational content of the broadcasts.

The arguments originally advanced by Congress in denying the right to sell time appear equally persuasive today. The potential benefits of such sale-additional operating funds-might be obtained by other means. In contrast, the harm effected by the sale of time-investing the educational process with commercial aspects unsuited to its healthy development-jeopardizes the very purpose of the stations. Accordingly, the Commission's original prohibitions should be maintained. Moreover, the FCC should modify the regulations to eliminate current quasi-commercial practices. Commercial enterprises should be prohibited from furnishing programs related to their business activity. Similarly, the requirement of identification should be waived for programs not concerned with public issues which are furnished by commercial firms. These reforms would eliminate a loophole in the noncommercial requirements of educational stations without impairing the protection the regulations were designed to afford. A more rigorous enforcement of the regulations to eliminate quasi-commercial practices should not deprive educational stations of substantial support.101 But it will prevent the gradual development of greater commercial orientation in the stations. To finance widespread programming of the type which Congress anticipated, educational television stations must look for greater aid to the educational institutions of their communities and to those private donors interested in the promotion of education. Short of this fuller public participation in financing, educational television will not be able to achieve full development without an undesirable change in the nature of its programming. ${ }^{102}$

101. At present, stations very rarely engage in these quasi-commercial practices, with the exception of acknowledging donations on the air. Questronsaines.

102. All educational television stations currently operating are exempt from taxation, either because they are instrumentalities of the government engaged in an essential governmental function, INT. REv. CODE of 1954, § 115(a) (1) ; cf. New York v. United States, 326 U.S. 572 (1946) (federal tax on sale of state-bottled mineral water upheld), or because they are organized exclusively for educational purposes, INT. REv. CoDE of 1954, $\S 501$ (c) (3). However, some stations derive a small part of their income from the rental or sale of broadcasting equipment and services or of programs they produce. QuestionNAIRES. For stations exempt under $\$ 501$ (c) (3), revenue from these activities may be subject to taxation at regular corporate rates as "unrelated business income" if the transaction is not substantially related to the tax-exempt purpose of the stations. INT. REv. CODE OF 1954, §§ 511-13. For interpretation of what constitutes unrelated income of a university, see REv. Rul. 55-676, 1955 Cun. Bull. 266. Exemption from taxation of the revenue from the rental or sale of kinescopes; the most common activity, would thus depend upon whether the kinescope was of an educational nature and whether it was being used for an educational purpose. Revenue from the rental or sale of a film for showing as a motion picture at a school or library should be exempt as a mere extension of the station's exempt function. But if the film were used by commercial television stations, motion picture exhibitors or industries, the Commissioner could impose a tax because the revenue was primarily for the purpose of increasing station income. Income from the use of educational facilities for the production of commercial programs or spot announcements would also be taxable. 


\section{LIABILITY FOR COPYRIGHT INFRINGEMENT}

Television programs make extensive use of musical compositions, dramatic works, literary materials, motion pictures, works of art and other property, rights in which are created and protected by the Copyright Act. ${ }^{103}$ To broadcast this material without risking liability for infringement, stations must obtain permission from the copyright proprietor. ${ }^{104}$ The performance rights to most copyrighted musical compositions are held by societies as licensees or assignees of the composers or publishers. ${ }^{105}$ While these societies generally require stations and networks to pay for a license to use compositions, ${ }^{106}$ they have offered gratuitous licenses to educational stations which agree to recognize society control and to observe restrictions on the performance of certain popular works. ${ }^{107}$

103. The Copyright Act grants the rights to make and sell copies of the copyrighted work, to translate the work or make other versions of it, to dramatize if it is a nondramatic work, to perform it publicly if it is a dramatic work, to perform it publicly for profit if it is a lecture, poem, essay or other nondramatic literary work or a musical composition, and to record it if it is a nondramatic literary, dramatic or musical work. 17 U.S.C. \$ 1 (1952).

104. Ibid. See Howell, The Copyright Law 120-53 (3d ed. 1952). As used herein, the word "proprietor" refers both to the copyright owner and the assignees of any of the specific rights included in the copyright owner's monopoly.

105. The three major performing-rights societies are ASCAP (American Society of Composers, Authors, and Publishers), BMI (Broadcast Music, Inc.), and SESAC (Society of European State Authors and Composers, Inc.). The Music Publishers Protective Association also licenses performances, but it is primarily concerned with the rights of mechanical reproduction. For a general discussion of the activities of these societies, see Warner, Ranto and Television Rights $\$ \S 130-38$ (1953).

ASCAP holds the nondramatic performance rights only, as grantee of its composer, author and publisher members. Finkelstein, Public Pcrformance Rights in Music and Performanic Right Societics, in CCH, 7 Copyrrget Problems Analdyzed 9 (1956). BMI secures the transforming and recording rights as well, often as vendee as well as licensee. For a description of BMII operations, see WARNER, op. cit. supra $\$ 137$ (a).

106. "Stations may have either a blanket or per program form of license. Both licenses are really on a blanket basis; that is, the license permits the station to play any composition in the licensor's repertory without separately negotiating therefor. The difference in the two types of license lies in the method of computing payments. Whereas, stations having a blanket license pay a percentage on all their receipts from the sale of 'time on the air,' those stations having program licenses pay on only those programs in which music in [ASCAP's] repertory is performed. The blanket radio license rate is only $2 \frac{1}{4} \%$, whereas the program rate is $8 \%$." Finkelstein, supra note 105, at 10.

A BMI single television station license provides for payments to BMI on a sliding scale ranging from $.81 \%$ to $1.09 \%$ of net receipts from advertisers (after deducting agency commissions and volume discounts). The scale is based on annual station income. See BMI, Single Television Station License, on file in Yale Law Library. .

107. Letter from Herman Finkelstein, General Attorney, ASCAP, to the Yale Law Jaumal, Nov. 5, 1957, letter from Theodara Zavin, Assistant Vice President, BMI, to the Yale Lazi Journal, Sept. 20, 1957, on file in Yale Law Library.

The restrictions usually apply to songs from stage shows or motion pictures and are designed to protect the shows against loss of receipts from indiscriminate performances of individual numbers on radio or television. See Finkelstein, sipra note 105, at 9. 
Some educational institutions have refused to apply even for these token licenses on the theory that their live performance of musical compositions and nondramatic literary materials does not constitute infringement under the act. ${ }^{108}$ The educators' argument stems from relevant provisions of the act which limit the proprietor's monopoly to instances of performance "for profit."109 For other materials, however, educational stations can make no comparable claim; the applicable sections of the statute do not incorporate the "for profit" qualification. Moreover, this limitation on the proprietor's rights cannot be invoked if the performance of musical compositions or nondramatic literary materials is rendered from a recording instead of delivered live.110

The legal sufficiency of the educators' assertion depends largely upon the rationale and judicial history of the "for profit" qualification. In any copyright system, the proprietor's interest in controlling his intellectual property conflicts with the public interest in its general circulation and enjoyment; every extension of copyright protection involves a concomitant withdrawal from un-

108. Examples of nondramatic literary materials include speeches, poems and the oral presentations of literature.

Four of twenty-three stations replying to QUESTroNNAIRES do not hold licenses. For an account of the origin of the controversy between ASCAP and some of the large midwestern universities, see WARNER, op. cit. supra note $105, \S 135 \mathrm{~d}$.

109. 17 U.S.C. $\S 1(\mathrm{e})(1952)$. The educators have not made the argument that a broadcast performance for educational purposes is not a "public performance." Under American law, broadcasting is a "public performance." Jerome H. Remick \& Co. v. American Automobile Accessories Co., 5 F.2d 411 (6th Cir. 1925). And the fact that the broadcast was educational would not make it less "public." Under the new English Copyright Act, however, a broadcast is not deemed a "public performance" if connected with school activities. See note 122 infra.

110. The visual part of a program can be recorded by an ordinary motion picture camera or by special kinescope recording equipment. The sound track can be recorded by wire, tape or electrical transcription. The simple making of a record should be distinguished from recording for the purposes of rebroadcast. If the former is considered a "copying" of the copyrighted work, rights attach under $\$ 1(a)$ of the act, which has no "for profit" limitation. Cf. Patterson v. Century Productions, Inc., 93 F.2d 489 (2d Cir. 1937), cert. denied, 303 U.S. 655 (1938), where the making of a positive from the negative motion picture film, and then negatives from the positive (a process similar to kinescope recording) was held to be the making of a "copy." Under this doctrine, the mere making of a recording, even if only for the purpose of creating a permanent reference library in the broadcast studio, would be prohibited. The problem is similar to that arising when libraries copy parts of copyrighted books to send scholars who cannot do their research in the libraries where the work is located. See Smith, The Copying of Literary Property in Library Collections, 46 LAw LiB. J. 197 (1953); 47 id. at 204 (1954).

A recording made for the purposes of rebroadcast could also be considered the making of a "copy" on the theory that "copies" appear on the television screen. Cf. Patterson v. Century Productions, Inc., sutpra. If it is a photoplay, it would also be protected without a "for profit" limitation as a "transcription or record" of a "dramatic work." 17 U.S.C. \$1(d) (1952). Universal Pictures Co. v. Harold Lloyd Corp., 162 F.2d 354 (9th Cir. 1947).

The "for profit" limitation is also missing from the recording provision of $\S 1$ (c), which relates to nondramatic literary property. But the committee report on this section nevertheless expresses the intention that the limitation apply. H.R. REP. No. 1160, 82d Cong., 1st Sess. 2 (1951). 
restricted public use. Musical compositions and nondramatic literary materials represent an especially important example of this conflict. For these are a common currency of popular culture. If rights in them are too broadly protected, every person singing a copyrighted tune or repeating parts of a copyrighted poem would be an infringer. Therefore, in granting copyright protection, Congress has sought to withdraw from public use only those performances which, if not protected, would result in confiscation of the proprietor's due reward-specifically, those performances which yield the infringer a monetary profit. ${ }^{111}$ When, in 1897 , Congress first extended copyright protection to musical compositions, all unauthorized performances were defined as infringements. ${ }^{112}$ Even attempts to exempt performances made "for charitable or beneficial purposes" were rejected, since Congress then felt the proprietor entitled to share in income derived from use of his property whatever the purpose of the performance. ${ }^{113}$ In an extensive re-examination of the act in 1909 , however, Congress sought a compromise which would give the proprietor due economic reward, yet permit harmless everyday performances of the material. ${ }^{114}$ The "for profit" limitation was inserted for this purpose. In addi-

111. Another possible basis for distinguishing nondramatic literary materials and musical compositions from other materials is the difficulty of determining the effect of noncommercial performances on the value of the performances for which the copyright proprietor does receive compensation. When a musical composition first comes to public attention, its performance on the radio, for example, might increase the sale of sheet music and records. But after continued performances, its popularity wanes.

This argument was advanced in some of the earliest congressional debates over protection of musical compositions. "[T] to have it sung upon the streets or played by a hurdy-gurdy because that brings it to public notice." 29 CoNG. REC. 87 (1896). Of course, commercial performances can be considered to have the same effect, and each commercial user wishing exemption from the copyright law has argued that his use should be encouraged, since it increases the proprietor's return from somebody else. See, e.g., Arguments Before the Committee on Patents on S. 6330 and H.R. 19853 To Amend and Consolidate the Acts Respecting Copyrights, 59th Cong., 1st Sess. 284 (1906) ; M. Witmark \& Sons v. Bamberger \& Co., 291 Fed. 776, 780 (D.N.J. 1923) (argument rejected).

112. The statute provided that any person publicly performing or representing any dramatic or musical composition for which a copyright had been obtained, without the consent of the copyright holder, was liable for infringement. Damages were assessed at not less than $\$ 100$ for the first performance and $\$ 50$ for each subsequent performance. Performances that were "willful and for profit" were punishable as misdemeanors by imprisonment for up to one year. Act of Jan. 6, 1897, c. 4, § 4966, 29 STAT. 482.

113. "If it is wrong to rob a man at all, is it not wrong to rob him through the operations of a church? For that is adding hypocrisy to theft." 29 CoNG. Rec. 88 (1896). The majority of the participants in this debate believed that extending copyright protection to nonprofit performances would not hamper nonprofit activities, since copyright owners would be willing to grant them permission to use their compositions without charge. In the words of one participant, "nobody wants to proceed against Sunday schools." Id. at 90.

114. "[T]here has been a very great protest on the part of many people against the drastic nature of the bill, proposing to punish the public performance of copyrighted music .... [T] hat is the present law .... There is no reason in the world why a child or a regi- 
tion, a separate exemption was created for choral works performed by public schools, church choirs or vocal societies, if the performance was "for charitable or educational purposes and not for profit."115

Unfortunately, the phrase "for profit" was not defined. Judicial construction has given it a very broad content. The public does not have to pay a fee t" receive the performance. Its "payment" and the resulting "profit" may be for food or lodging at the place where a work is offered as entertainment.116 Nor need the "profit" be definitely ascertainable. In the broadcasting field, protection has been held to attach to performances involving goodwill or product advertising for a commercial organization..$^{117}$ As long as the unauthorized use of a copyrighted work is designed to produce revenue, the courts will apparently find an infringement.

In American Federation of Musicians $v$. Debs Memorial Ass'n, these principles were applied to a noncommercial enterprise. ${ }^{118}$ An infringement suit had been initiated against a nonprofit corporation organized to promote civic, educational and cultural purposes. The defendant admitted unathorized use of copyrighted material by its subsidiary radio station but denied that it constituted infringement. Pointing to its nonprofit status and alleging that the use of copyrighted material was limited to nonsponsored- "sustaining"-broadcasts, defendant invoked the "for profit" limitation on the proprietor's rights. Nevertheless, infringement was found. The court offered alternative theories

mental band passing down the street singing or performing a copyrighted piece of music should be penalized for the act when it is a mere matter of entertainment and a mere matter of the use of music which has been been bought or learned. The thing to be protected is the business of the music publishers, and not to cut off the public from the enjoyment of the music which can be received or enjoyed by any mode in which it is publicly performed." Testimony of Arthur Steward, Chairman, Copyright Committee, American Bar Association, Arguments, supra note 111, at 162.

115. 17 U.S.C. $\$ 104$ (1952). This exemption has been interpreted as allowing the covered noncommercial arganizations to charge admission fees for their performances, provided the money is used for a charitable and educational purpose. See Church Co. v. Hilliard Hotel Co., 221 Fed. 229, 230 (2d Cir. 1915).

116. Herbert v. Shanley Co., 242 U.S. 591 (1917) (copyrighted work played as entertainment in restaurant); Buck v. Russo, 25 F. Supp. 317 (D. Mass. 1938) (same); Buck v. Pettijohn, 34 F. Supp. 969 (E.D. Tenn. 1940) (night club) ; Buck v. Dacier, 26 F. Supp. 37 (D. Mass. 1938) (same) ; Buck v. Jewell-LaSalle Realty Co., 32 F.2d 36r, (I). Mo. 1929), rev'd in part, 283 U.S. 191, 198-99 (1931) (hotel).

117. Jerome H. Remick \& Co. v. General Elec. Co., 4 F.2d 160 (S.D.N.Y. 1924), 16 F.2d 829 (S.D.N.Y. 1926) ; M. Witmark \& Sons v. Bamberger \& Co., 291 Fed. 776 (D.N.J. 1923) (copyrighted music played on radio station owned by defendant whose sole commercial was announcement made before and after each program: "L. Bamberger and Company, one of America's Great Stores"); See Jerome H. Remick \& Co. v. American Automobile Accessories Co., 5 F.2d 411, 412 (6th Cir. 1925) (copyrighted music played on station owned by defendant, which used station to advertise radios sold by it): "It is immaterial, in our judgment, whether that commercial use be such as to secure direct payment for the performance by each listener, or indirect payment, . . . when no admission fee is required, or a general commercial advantage, as by advertising one's name in the expectation and the hope of making profits through the sale of one's products . ..."

118. 141 F.2d 852 (2d Cir.), cert. denied, 323 U.S. 766 (1944). 
for imposing liability despite the nonprofit nature of the defendant: "Both in the advertising and sustaining programs [one third of the station's programs were sponsored], Debs was engaged in an enterprise which resulted in profit to the advertisers and to [sic] an increment to its own treasury whereby it might repay its indebtedness to [the parent] . . . and avoid an annual deficit." 119 In both these respects, the court found that the copyright proprietor had a statutory right to prevent the realization of income in which he was not accorded an opportunity to share. ${ }^{120}$ It also noted that station employees received a salary.

If the Debs approach is followed, educational television stations will be regularly subject to liability for unauthorized uses of copyrighted materials. Performances of copyrighted material on programs furnished by commercial enterprises would clearly be for profit when the donor received credits or the benefit of silent commercials. Even programs furnished by noncommercial institutions could be included within the $D e b s$ reasoning since utilization of such programs reduces the production expenses of the educational station and its ownership organization. Similar treatment would attend the use of copyrighted material on college telecourses which involve registration payments that augment the treasury of the ownership organization. ${ }^{121}$ Under the broadest language of $D e b s$, educational broadcasts would be "for profit" irrespective of their nature, for production involves incidental wage payments to station personnel. ${ }^{122}$

119. 141 F.2d at 855 . Debs claimed it accepted just enough advertising to cover its uspenses and a reasonable reserve for contingencies.

120. See ibid. The court drew no distinction between these possible sources of "profit," finding it was "unimportant whether a profit went to Debs or to its employees or to the advertisers."

121. Students who wish to take the telecourses for credit must enroll and pay registration or tuition fees. Some stations also charge fees for notes and syllabi used in connection with the courses. Questronnaires. The FCC has approved this method of financing. See Texas Technical College, 16 Radro Reg. 46 (1957).

122. Interpreting the Canadian Copyright Law, which exempts certain nonprofit performances, Canadian courts have passed on some of the issues not yet before United States courts. The decisions have favored the copyright proprietor over the noncommercial organization.

The Canadian act provides: "No church, college or school and no religious, charitable or fraternal organization shall be liable to pay any compensation to the owner of any musical work or to any person claiming through him by reason of the public performance of any musical work in furtherance of a religious, educational or charitable object." Can. Rev. Stat. c. 55, § 17(3) (1952). In Composers, Authors and Publishers Ass'n, Ltd. v. Kiwanis Club of West Toronto, [1953] 2 Can. Sup. Ct. 11, infringement was found where a paid archestra performed a copyrighted work at a dance sponsored by a nonprofit fraternal organization. The proceeds of the dance were used for charitable work The court held that for the exemption to apply the performance itself must further the charitable object.

Another provision of the Canadian act exempts from liability a performance "without motive of gain of any musical work at any agricultural, agricultural-industrial or industrial exhibition or fair which receives a grant from or is held under Dominion, provincial or 
Whether or not Congress intended the "for profit" provision to be as broad as the Debs construction is uncertain. Neither the debates nor the committee reports suggest an intent to exempt anything but everyday performances. Indeed, the presence of a specific exemption for charitable choral renditions might be construed to require express terms to remove other performances from the all-encompassing "for profit" provision. ${ }^{123}$ Additional confusion results from the committee report adopted in 1952, when Congress extended the "for profit" qualification to nondramatic literary materials. ${ }^{124}$ The report recommends that Congress accept the judicial definition of "for profit." It refers to this formulation as a "material, tangible, commercial profit."125 By stressing the commercial aspects of a performance, the report appears to suggest that live broadcasts of musical compositions or nondramatic literary materials by educational television stations would not constitute infringing uses. However, while no case has directly decided whether a performance by a completely noncommercial organization which involved incidental financial receipts or pay-

municipal authority by the directors thereof." $C_{\text {AN. }}$ REv. STAT. c. 55, $\S 17(2)$ (g) (1952). In Composers, Authors and Publishers Ass'n, Ltd. v. Western Fair Ass'n, [1951] Can. Sup. Ct. 596, 599, 2 D.L.R. 229, 239 (1952), the court found infringement where the copyrighted work was played by a paid band at a federal fair which charged admission fees. The court said that whether or not the defendants had a "motive of gain," the band had such a motive, and the statute did not exempt the performance.

The English Copyright Act protects the public performance, specifically including the broadcasting, of a literary, dramatic or musical work without requiring the performance to be for profit. See Copyright Act, 1956, 4 \& 5 Eurz. 2, c. 74, \$§ 2(5) (c), (d). However, the use of copyrighted materials for instruction in schools is not an infringement. Id. $\S$ 41(1)(a). And noninstructional performances are not deemed "public performances" if they are given in schools or "in the course of the activities of a school." Id. $\$ \$ 41$ (3) (a), (b). Television broadcasts are included in the exemption. Id. $\S 41(5)$. Under these sections, educational television programs for in-school purposes would receive exemption from the Copyright Act, while general adult education programs would not.

123. See note 115 supra and accompanying text.

124. The purpose of the amendment was to extend performance and recording rights to nondramatic literary works, which had not been covered by the act of 1909 . The original house bill, as introduced, did not restrict copyright protection to performances for profit. The Committee inserted the phrase, pointing out that without it, "a teacher reading excerpts from a copyrighted schoolbook in a schoolroom, a minister reading from text in a church, or a speaker at a civic meeting would be held to have infringed the copyright." H.R. REP. No. 1160, 82d Cong., 1st Sess. 2 (1951). Significantly, both the teacher and minister are "paid," and incidental payments for ushers, janitors, police and fire protection are necessary to hold the civic meeting.

125. The Conference Committee considered this issue because the Senate had amended the bill to read "for pecuniary profit." 98 ConG. REc. 7808-09 (1952). The conferees struck out the word "pecuniary" because they believed "that the objective of the ... Senate amendment is obtained without the addition of the word 'pecuniary', and that the addition of such word may create uncertainties in the law. The concept of 'public performance for protit' has been in the Copyright Law since 1909 and the courts have construed the phrase to mean a material, tangible, commercial profit. The inclusion of the phrase 'pecuniary' might cast doubt upon the phrase 'public performance for profit' appearing elsewhere in the law." Conference Rep. No. 2470, 82d Cong., 2d Sess. (1952), 2 U.S. Cone Cong. \& Ad. NEwS 2307 (1952). 
ments would amount to an infringement under the Copyright Act, the trend of decisions, and especially the language in Debs, indicates that it would. The report's dependence on court decisions accordingly renders questionable the value of its definition as the most recent declaration of congressional intent.

At present, the effect of the "for profit" limitation is of little practical significance either to educational stations or to copyright proprietors. Free licenses for musical compositions - the predominant class of copyrighted material used by educational stations-are granted on request. Those stations which refuse to apply for licenses are collecting copyright-free music libraries. ${ }^{126}$ And since educational stations operate on a very modest scale, copyright proprietors are not presently deprived of significant income. If, however, educational television develops as expected and desired, the scope of the "for profit" provision will be of greater import. In this event, the conflicting interests of the public and the proprietor should be balanced. Against the latter's obvious economic interest is the educational station's desire to make its programming more attractive. The present confusion surrounding the "for profit" limitation suggests that Congress define the appropriate balance. If it decides that educational exemption is desirable, it should enact new legislation along the lines of the existing exemption for choral works. The amendment might provide that licensed educational institutions may broadcast musical compositions and nondramatic literary materials if the program serves educational purposes and no profit is to accrue to any profit-making institution.

\section{Right of Privacy}

Protection of the person from unauthorized publicity is a right recognized in twenty-seven jurisdictions. ${ }^{12 \pi}$ Developed at the end of the nineteenth century in response to the growth of media of mass communication, the right of privacy is based on the theory that widespread circulation of a person's name, likeness or affairs, even in a nondefamatory manner, can cause mental or emotional distress. ${ }^{128}$ Given an unauthorized publication, damages are presumed; the plaintiff can recover unless the circumstances give rise to a privilege. ${ }^{129} \mathrm{~A}$ majority of the jurisdictions that recognize the right accord such a privilege to invasions which involve the dissemination of information in which the public has a legitimate interest. Thus, persons present at public spectacles or news-

126. These libraries consist of public domain works and recorded foreign compositions, the copyright proprietors of which have not attempted to obtain copyright protection in the United States. Questronnarres. For provisions relating to reciprocal copyright agreements with foreign nations, see 17 U.S.C. $\$ 9$ (1952).

127. Restatement, Torts $\$ 867$ (1939); Cases and statutes are collected in 1 Harper \& JAMEs, ToRTs $\$ 9.6$ (1956).

128. Warren \& Brandeis, The Right to Prizacy, 4 Harv. L. Rev. 193, 196, 213 (1890). This was the first article to advocate independent recognition of the right of privacy. For discussion of the subsequent development of case and statutory law, see Nizer, The Right of Privacy: 4 Half Century's Developments, 39 Mich. L. Rev. 526 (1941); Shipley, Privacy Invasion by Telecast, 15 FEv. B.J. 186 (1955).

129. See 1 Harper \& James, Torts $\$ 9.7$ (1956). 
worthy events are denied recovery when their likeness is published as part of the news coverage. ${ }^{130}$

Although the right of privacy problems confronted by educational broadcasters often parallel those of commercial stations, the legal implications differ in several important respects. Educational stations owned by instrumentalities of the state enjoy immunity from suit under the widely criticized but judicially entrenched doctrine exempting public educational institutions from liability for their torts. ${ }^{131}$ Of course, stations owned by private educational institutions would not share this immunity. Nor would publicly owned outlets when the invasion occurred on a program so unrelated to the educational purpose of the station that the broadcast amounted to a "proprietary" activity. ${ }^{132}$

Absent immunity, the noncommercial nature of educational stations should not affect their liability for invasion of privacy. Statutes in some states confine liability to invasions for commercial purposes. ${ }^{133}$ Moreover, in determining the existence of a public-interest privilege, many courts have distinguished between invasions for advertising and "noncommercial" purposes. As applied to publications in newspapers and periodicals, this distinction allows the privilege to attach to material in the news and feature columns but makes actionable all invasions found in advertising matter. ${ }^{134}$ Carried over to educational television, it would offer protection to all programs except those granting some form of commercial credit. This result would be unfortunate, for the distinction is artificial even in its own field. A newspaper, for example, prints news at least in part for a commercial purpose-to draw readers to its advertising. Moreover, the right of privacy is designed to prevent mental distress, not unjust enrichment of the publisher ;135 and such distress may result equally from

130. Gautier v. Pro-Football League Inc., 304 N.Y. 354, 107 N.E.2d 485 (1952) (plaintiff's animal training act televised between halves of professional football game); Jones v. Herald Post Co., 230 Ky. 227, 18 S.W.2d 972 (1929) (street assault) ; Humiston v. Universal Film Mfg. Co., 189 App. Div. 467, 178 N.Y. Supp. 752 (1st Dep't 1919) (murder); Cook v. Twentieth Century-Fox Film Co., cited in Nizer, supra note 128, at 546 n.65. But cf. Leverton v. Curtis Publishing Co., 192 F.2d 974 (3d Cir. 1951) (even though event newsworthy, publication made for different purpose).

131. 2 Harper \& Janes, Tokts $\$$ 29.16-.17 (1956) ; see PoE, Schtor. Liarility ful Irjuries to PuplLs 43-71 (1941). See also Note, 40 Minn. L. Rev. 234 (1956).

132. 18 MCQUillin, Municipal. CoRPoRations $\$ \S 53.23-.24$ (3d ed. 1950). When the sovereign engages in activities usually conducted by private enterprise, the cases differ on whether the activity is proprietary. Compare United States v. Northwestern Nat'l Bank \& Trust Co., 35 F. Supp. 484 (D. Minn. 1940) (postal money order system held governmental) ; Brams v. State, 63 S.D. 571, 262 N.W. 89 (1935) (coal mining held governmental), with Grand River Dam Authority v. Grand-Hydro, 188 Okla. 506, 111 P.2d 488 (1941) (government agency furnishing water held proprietary). Although the operation of television stations is normally a private function, when undertaken for educational purposes, it would probably assume the governmental character of education.

133. See N.Y. Civ. Rights Law $\$ \$ 50-51$; UTAB Code ANN. $\$ \S 76-4-7$ to -9 (Supp. 1957) ; VA. Code ANv. \$ 8-650 (1950).

134. See Sidis v. F-R Publishing Corp., 113 F.2d 806, 809-10 (2d Cir. 1940). See also cases collected in 1 HARPER \& JaMES, TORTS $\$ 9.7$ (1956).

135. See Nizer, supra note 128 , at $\mathbf{5 5 0 .}$ 
invasions serving commercial or noncommercial purposes. While a public-interest privilege should be recognized, it should not be confused with the economic motivation of the potential invader.

In educational television, the applicability of the public-interest privilege will be particularly difficult to determine when the challenged broadcast emanates from a classroom. Such broadcasts comprise one of the more important activities of an educational station. ${ }^{136}$ Still, if a camera transmits the image of an ugly, deformed or even excessively shy child, or carries his embarrassingly poor recital, his privacy may be invaded. ${ }^{137}$ In this event, the privilege should depend on the nature of the telecast. The class may have been broadcast on a closed circuit, with its viewers limited to other in-school students. ${ }^{138}$ $\mathrm{Or}$, it may have been televised on an open circuit for instructional purposes or to familiarize the public, especially parents, with the operation of classes. ${ }^{130}$

When the broadcast is on closed-circuit facilities, the case for privilege is strongest. A child attends school at the command of the state, which acts to promote the public interest by giving its children the maximum practicable jublic education. This very attendance necessarily involves an invasion of the privacy enjoyed in a home. In school, the child must expose himself to the oft-critical gaze of his classmates. But he could not complain that this compulsion violated his right of privacy. ${ }^{140}$ Nor would his rights vary with the size of the classroom. In a sense, a closed-circuit telecast merely enlarges the classroom by expanding the number of students able to view the child's activities. This expansion should not prevent the privilege from attaching.

An open-circuit broadcast designed to show citizens their schools in action would also seem a proper occasion for application of the privilege. As parents

136. QUESTIONNAIRES.

137. Bazemore v. Savannah Hospital, 171 Ga. 257, 155 S.E. 194 (1930) (photograph of deformed baby) ; Ops. ATT'Y GEN. NEW YORK STATE 374 (1934) (pictures of persons with malignant diseases). The privacy of the parent may also be invaded. Bazemore $v$. Savannah Hospital, supra; Clayman v. Bernstein, 38 Pa. D. \& C. 543, 549 (C.P. 1940) (husband can recover damages for invasion of wife's privacy).

138. Under this procedure, activities in one class are broadcast to other classrooms in which students are learning the same subject. The receiving classes may have teachers of their own to supplement the telecast with discussion, questions, etc. Sometimes students in other classes can ask questions of the television teacher by means of a two-way aural connection. For descriptions of various methods of closed-circuit television teaching, see Lakal, The Schools of Tomorrow, Saturday Review of Literature, Aug. 24, 1957, p. 9; Broadcasting-Telecasting, Nov. 11, 1957, p. 97.

139. "Innacents, unaware that they are starring in the Know Your Schools series on KRNT-TV, Des Moines go about regular class pursuits in uninhibited fashion. To telecast the realistic daily series, the station and school advisors [conceal] cameras . . . and lights and mikes behind a ceiling grid. ... The show also acts as a sounding board for public reaction to educational tw in the Des Moines area." Broadcasting-Telecasting, June 3, 1957, p. 62 .

140. In cases involving an invasion of privacy resulting from performance of a governmentally imposed duty, courts have refused to grant relief. See Merle v. Sociological Research Film Corp., 166 App. Div. 376, 152 N.Y. Supp. 829 (1st Dep't 1915) ; Freed v. Loew's Inc., 175 Misc. 616, 24 N.Y.S.2d 679 (Sup. Ct. 1940) (semble). 
and taxpayers, the viewers would have a legitimate interest in inspecting the operation of their schools, an interest that could be effectively served by the broadcast of selected classroom proceedings. ${ }^{141}$ Although presence in a classroom need not effect as broad a waiver of privacy rights as attendance at a public spectacle, the community interest in this regard should outweigh an individual child's right of privacy.

When the class proceeding is broadcast on an open circuit as part of an instructional program, however, the privilege becomes more difficult to establish. Its application should depend upon whether the plaintiff-student's appearance is necessary to the instruction. ${ }^{142}$ Most instructional programs employ lectures and demonstrations, which can be broadcast as effectively from a studio as from a classroom. On the other hand, other forms of instruction, such as seminars and discussion groups, require student participation. In an action brought by a student, the courts, while alert for abuse of the public interest privilege, should accord great weight to the instructor's determination of necessity, which presents itself for judicial approval recommended by experience in technique and desire to develop the most effective class presentation. ${ }^{143}$

\section{ConcLusion}

Educational television poses a new demand for an intelligent weaving of noncommercial and nonprofit activities into a legal framework developed for business operations. Diverse governmental agencies must deal with the resulting problems. The FCC should continue to re-examine educational reservations, since the possibility of deletion spurs greater progress by potential educational licensees. At the same time, it should give greater consideration to the educational need of the community in judging deletion requests. State legislatures should amend restrictive laws to allow station operation by all qualified groups, private and public. Between commercial and noncommercial stations, audience competition should be fostered, for the result is improved program-

141. For a parent, watching a televised classroom is a more efficient way of learning about his schools than reading the annual report of a school superintendent. And a child's picture published as part of such a report would be privileged.

142. The necessity doctrine has been utilized in Gill v. Curtis Publishing Co., 38 Cal. 2d 273, 239 P.2d 630 (1952) ; Blumenthal v. Picture Classics, 235 App. Div. 570, 257 N.Y. Supp. 800 (1st Dep't 1932), aff'd, 261 N.Y. 504, 185 N.E. 713 (1933).

143. Some educational stations have attempted to avoid the privacy problem by pro. curing signed releases from parents, which waive all claims growing out of the appearance of their children in televised classrooms. QuEsTronnarres. The right of privacy can be released if the plaintiff knows the nature of the prospective use of his likeness. Recd v. Real Detective Publishing Co., 63 Ariz. 294, 162 P.2d 133 (1945); Marek v. Zanol Products, Inc., 298 Mass. 1, 9 N.E.2d 393 (1937) ; Harlow v. Buno Co., 36 Pa. D. \& C. 101 (C.P. 1939). Minors, however, cannot waive it for themselves. See cases collected at 92 C.J.S. 1066 (Supp. 1957). If the station is operated by a school or other public educational authority, releases may not be necessary since, in the absence of statute, a school is immune from tort liability arising out of its educational functions. PoE, op. cit. supra note 131 , at 52 . However, immunity would not extend to a station unaffiliated with a school system. 
ming of both. But sponsor competition should be prohibited. Finally, the application of commercially oriented tort and copyright doctrines should rest on a judicial-and, in the case of copyright, a congressional-determination of whether the value of educational programming to the public outweighs the personal rights of the student or the property rights of the copyright proprietor. In all cases, a constant balance of the conflicting demands between individual and community, between commercial and noncommercial institutions, should be maintained, so that erosion of legitimate opposing interests will not mar educational television's increasing contribution to the intellectual development of the population. 